\title{
Una mala fe. Campaña de extirpación de idolatrías. A propósito de una obra del P. Pablo José de Arriaga, S.J.
}

\author{
Pedro Trigo, \\ Centro Gumilla, \\ Caracas, Venezuela.
}

\section{Introducción: una obra militante}

Extirpación de la idolatría del Pirü*, obra escrita por el jesuita Pablo José de Arriaga, vio la luz en Lima en 1621. No es crónica ni etnología ni etnngrafía ni historia, "aunque se podía hacer muy larga y muy varia de las antiguallas, fábulas, ritos y ceremonias que tenían, y no acaban de dejar, los indios de estos reinos en su gentilidad" (193). Para ese fin recogía por entonces materiales otro jesuita, Bernabé Cobo, con miras a una especie de historia natural y moral de las Indias, que sólo en parte nos es conocida, al estilo de la de Acosta, pero disponiendo de mucha más documentación. La obra de Arriaga ofrece abundante material etnográfico, ya que recoge numerosos testimonios de adoratorios, imágenes, adminículos para el culto y ofrendas, en el acto de descubrirlos, destruirlos y reprimir a sus ministros y fieles; así como también es referencia obligada para los etnólogos ya que ofrece una sistematización clara y coherente de la religión de los indígenas. La curiosidad, como él dice, es decir, el deseo de entender el mundo religioso indígena, es sin duda un ingrediente de esta obra. Pero no es ese su intento. El fin que pretende es "descubrir y remediar un mal tan mal encubierto" (194).

La obra forma parte de la campaña de extirpación de idolatrías, que diera comienzo en 1608 el cuzqueño mestizo Francisco de Avila, cura de Huarochiri. La relación de la obra que comentamos con esta campaña no estriba sólo en el

* Utilizamos la edición que se encuentra en Crónicas peruanas de interés indígena, Biblioteca de Autores Españoles n̊2 209 (Madrid, 1968) 191-277. 
contenido, sino también en el modo como fue compuesta: "andando en la visita de la extirpación de la idolatría con otros dos Padres de nuestra Compañía, con el doctor Hernando de Avendaño" (173), visitador y principal fautor de esta campaña, junto con Avila, a quien nuestro autor también acompañó varios meses en su visita. Así pues, es una obra militante, escrita sobre la marcha, al pulso de los acontecimientos, penetrado el autor de la realidad de lo que escribe y de los sentimientos y reacciones que ello le suscita. Y no sólo eso. A pesar de las dificultades geográficas, los promotores de la campaña reciben correspondencia abundante, y el escrito da cuenta paso a paso de lo que le informan los curas doctrineros u otros misioneros sobre el avance de la campaña, de modo que por momentos tenemos la sensación de asistir a una ofensiva fulminante de detención, asedio y asalto a las fortalezas que el diablo habría armado, guarecido y solapado. Se puede afirmar que cada palabra de la obra está penetrada del objetivo y fin proclamado de descubrir las idolatrías y erradicarlas.

El cuerpo central del libro, el que parece haber sido escrito durante la visita, es un tratado que comprende tres partes: 1) descripción sistemática de la idolatría de los indígenas; 2) causas de que ésta se haya mantenido por tanto tiempo y de que rebrote fácilmente; y 3) remedios para erradicarla, tanto los remedios estructurales y permanentes, como el remedio próximo imprescindible de la visita-misión, cíclicamente reiterada. Pero, puesto que el mal está tan escondido que muchos que tienen autoridad podrían no dejarse convencer por un mero tratado, se añade a la obra una relación en tres partes: 1) una crónica introductoria sobre el modo como comenzó a descubrirse la idolatría en el arzobispado de Lima, 2) cartas de misioneros y curas para probar, a modo de autoridades, que en las provincias no visitadas hay muchas idolatrías y que también quedan en las visitadas, y 3) la descripción de cómo van aplicándose los remedios en el arzobispado y en otros lugares del virreinato en el momento en que se imprime el libro en el año 1621.

El tratado habría sido escrito entre 1617 y 1618 , que es la fecha de la visita, y la crónica sería del 1621. Lo que sucedió entre ambas fechas fue una amplísima consulta sobre la obra, tanto interna, en la Compañía de Jesús, como de los cinco visitadores, el virrey, el arzobispo, el fiscal y diversos consultores cualificados. Aunque el autor afirma que no escribió la obra para su publicación, sino para la discusión, el virrey, que oyó de ella y la leyó, pidió que se imprimiera y de ahí que hubiese tanta consulta sobre la obra. Según el autor "todos convinieron en que se imprimiese" (194) y fueron los jesuitas los que más lo discutieron, porque respecto de las idolatrías de los indios "algunos lo dudaban y otros no lo creían" (id.) y así el provincial había "mandado quitar algunas cosas que podían ser inconveniente andar impresas" (id.). Así, pues, la historia de la composición de la obra y la de su publicación hacen ver que ella forma parte de una campaña vasta y aguerrida, y que es una pieza crucial de ella, tanto para convencer a las autoridades, curas y misioneros de la urgencia impostergable de acometerla con 
todas las fuerzas, como para dar armas a los que la van a librar, que son sobre todo los curas y también los misioneros.

En este artículo comenzaremos exponiendo la visión de Arriaga sobre la religión indígena, las causas de que perdure y los medios para extirparla, y seguidamente ofreceremos una discusión sobre su planteamiento religioso, las causas de la idolatría y sus remedios. Este artículo pretende ser, por lo tanto, un comentario de textos.

\section{Resumen de la obra}

\subsection{La religión indígena}

La parte primera de la obra, que describe la religión indígena, comprende cinco capítulos: los ídolos, sus ministros y ofrendas, las fiestas y las supersticiones. Así lo describe el autor.

\section{a) Los ídolos}

Llaman huacas a aquello que "adoran como a Dios" (202). A las huacas las adoran, invocan, reverencian, les piden "y tienen sobre ellas mil fábulas de conversiones y metamorfosis" (201). Ante todo están las huacas "fijas e inmóviles" que son las de la naturaleza: el sol, la luna, algunas estrellas y el rayo, que serían las divinidades celestes, a las que se pide ayuda. Los serranos cuando van a trabajar a la costa se dirigen a Mamacocha, la mar, le piden que no enfermen y poder regresar con salud y plata. A Mamapacha, la tierra, la invocan sobre todo las mujeres al sembrar pidiéndole buena cosecha. A los Puquios, manantiales, les invocan para que no se sequen. A los ríos torrentosos que bajan de la sierra les suplican que les dejen pasar y que no se les lleve la corriente. Veneran a los cerros, a algunas piedras enormes, a los nevados, y les piden protección. Algunos cerros, nevados, puquios o cuevas son Pacarinas, es decir, de donde desciende un ayllu, pueblo o grupo étnico, y, por lo tanto, de donde sacan su fuerza vital y protección. Y esa sería una de las razones por las que no quieren mudarse de lugar y regresan a él en cuanto pueden abandonar las reducciones. También veneran al Huari que son los primeros pobladores, seres gigantes, y les piden fuerzas para hacer casas o chacras. El autor insiste en que, ya que no pueden quitarse estas huacas de la vista, se procure quitarlas del corazón, desencantando, para ello, la naturaleza con explicaciones científicas.

"Otras huacas hay móviles, que son las ordinarias" (202). Son ídolos, la mayoría de piedra, sin figura o con figura de animales o humana. "Y no hay que admirarse que en cosas tan pequeñas reconociesen deidad los indios. Porque es cosa cierta y averiguada que estas figuras y piedras son imagen y representación de algunos cerros, de montes y arroyos o de sus progenitores y antepasados" (196). Las tienen como guardas y abogados de sus ayllus, las invocan y de ellas 
esperan su bien y felicidad.

Los malquis (sierra) o munaos (costa) son cuerpos o huesos de sus antepasados ilustres, que dicen ser hijos de las huacas y están enterrados en sepulturas de bóveda llamadas machays, en lugares apartados, vestidos de ropas finas y rodeados de ofrendas como las huacas.

Las conopas o chancas son piedrecitas con alguna señal o forma curiosa, consideradas como dioses lares, "el mayordomo o dueño de casa" (203). Se heredan de padres a hijos, y otorgan comida y descanso. Se las venera como a las huacas, pero su adoración y culto es particular de los de cada casa. Las veneran cuando están enfermos, cuando salen de viaje, al comenzar la siembra. También hay conopas para el maíz, la papa o el ganado. La chacra tiene su huaca particular, llamada huaca o chíchic. Es su dueña y se la reverencia y ofrenda un tributo cuando se entra en ella a sembrar. También las acequias tienen la suya y la veneran para que no se quiebren y les falte el agua. Para que la cosecha sea abundante hacen muñecas de maíz o de piedra en forma de maíz; y lo mismo para la coca.

Las cunas son también veneradas y se les pide que guarden a los niñitos que quedan en ellas.

\section{b) Los ministros}

Los ministros más importantes de la religión indígena son los encargados de las huacas, sobre todo los de las más principales. Conocen sus fábulas, hablan de ellas, les llevan las ofrendas, hacen los sacrificios, preparan las fiestas y ofician en ellas. Lo mismo hacen los encargados de los malquis o del rayo o el sol. Estos ministros suelen tener un ayudante.

Está también el que cura por el conocimiento que tiene de yerbas. Comúnmente, a su intervención, digamos técnica, precede un sacrificio a la huaca o a la conopa del enfermo. El confesor es afín al que cura. Ejerce su oficio para la comunidad como una parte preparatoria de la fiesta de la huaca y a los particulares que se lo piden en caso de enfermedad o al emprender un viaje largo. Otro oficio indispensable es el de preparar la chicha para las fiestas y ofrendas a las huacas (en la sierra con mujeres). Para esto la huaca tiene su chacra y es la primera que se cosecha. No falta tampoco el que adivina sobre los sucesos que acaecen, mediante maíces, piedritas, arañas, cuyes o sueños.

Se puede llegar a ser sacerdote de varias formas: por sucesión, por elección o por propia cuenta. Por ejemplo, la comunidad puede desposar con la huaca a muchachas de especial belleza, mientras que un herido de rayo o alguien que sea presa de ataques puede ser considerado como elegido por una huaca, ya que esas experiencias pudieran ser consideradas como iniciación. Por su parte quienes son viejos(as) inútiles para el trabajo pueden dedicarse a ese oficio como medio de vida. Para entrar en él debe preceder un tiempo de preparación que incluye siempre el ayuno. 
"Fuera de todos estos hechiceros los que merecen más propiamente este nombre son los Cauchus que se descubrieron en los pueblos de los llanos y costa. Costó descubrillos mucha dificultad y trabajo por el grande secreto que tienen entre sí, y porque temen a estos tales grandemente todos los indios" (2078) porque matan gente, sobre todo muchachos, en gran número. Actúan de noche. Reúnen a sus discípulos y salen a hacer sus maleficios. Adormecen con polvos de huesos y otras sustancias a los habitantes de una casa, entran a chupar algo de sangre de la futura víctima, luego la cuecen y comen, y a los días muere, viendo en su agonía la cara de quien lo chupó. En esas juntas se aparece el demonio y lo adoran.

\section{c) Las of rendas}

Las ofrendas a las huacas, malquis y conopas consisten en cosas con que los rocían o soplan, o sustancias que qucman frente a ellos. "La principal ofrenda, y la mejor, y la mayor parte de sus sacrificios es la chicha; por ella y con ella comienzan todas las fiestas de las huacas, en ella median y con ella acaban sus fiestas, y ella es todo" (209). Para hacer la ofrenda, como dijimos, tienen reservadas chacras y personas. También la coca "es universal ofrenda a todas las huacas y en todas las ocasiones" (210). Para producirla tienen chacras especiales. "El sacrificio ordinario es de cuyes" (id.) con los que, como dijimos, adivinan al sacrificar. En las fiestas más solemnes de las huacas ofrecen llamas y en primer lugar el corazón y la sangre, la carne sirve de banquete de comunión. El sebo se quema delante de la huaca, con maíz y coca. A veces se hace con él una figurita y al quemarla, se quema el alma de la persona aborrecida para que quede sin entendimiento ni corazón. También se ofrecen frutos secos que parecen ser medicinales, polvos minerales de colores vistosos, conchas gruesas de mar con cuyos pedazos adoman de collarcs a las huacas, plata y pestañas que se arrancan y soplan hacia el ídolo.

\section{d) Las fiestas}

Las fiestas solemnes las instituyeron las mismas huacas a quienes se honra. Las principales son tres al año, relacionadas con el ciclo del maíz: hacia principios de junio para que no se seque el maíz, por navidad para que llueva, y cuando lo recogen. El sacerdote mayor avisa a los curacas para que se prepare la chicha y a todos para que lleven sus ofrendas. El día señalado las ofrece y también ofrece a las huacas menores y a los malquis. Esa noche se vela cantando, bailando y contando historias, y da comienzo el ayuno, que dura cinco días o más y consiste en comer sin sal ni ají, y en abstinencia sexual. Durante el ayuno tienen lugar las confesiones, que son muy estrictas. Los pecados que se confiesan son el robo, el maltrato, el adulterio, la haraganería, la desobediencia a los curacas y el no acudir a sus huacas. La penitencia consiste en más ayunos y abstinencia sexual. Acabada la penitencia, visten sus trajes ceremoniales y beben, bailan y cantan invocando a la huaca y recordando sus fábulas. 
El sacerdote pide para la comunidad a la huaca vida, salud y buenas chacras. Para apoyar su oración le lleva las ofrendas. La trata como señor y creador del ser humano, y considera a los oferentes como sus hijos y creaturas. El rito de adoración-invocación se llama mochar y consiste en levantar la mano izquierda abierta hacia la huaca como enviándole un beso y ofrecerle pestañas, chicha y lo demás, mientras reza haciendo ruido con los labios como si los chupara bruscamente (que eso significa literalmente mochar). Este mismo modo usan también los particulares con el sol, el rayo, la Pachamama, la Mamacocha, la huaca de la chacra... Es también frecuente mingar, que significa alquilar al sacerdote para que moche a la huaca en caso de enfermedad o por algún trabajo o en favor de la sementera o para confesarse. "Y fuera de las ocasiones de fiesta, enfermedades, sementeras o algunos trabajos que les sobrevienen, no se acuerdan mucho de sus huacas, ni aun a las conopas o dioses penates que tienen en casa tampoco las mochan si no es en los tiempos dichos" (214).

\section{e) Supersticiones y errores}

Entre las supersticiones más notables están los ritos de pasaje. Al cortar el pelo por primera vez, que suele ser de cuatro o cinco años, ayunan y luego organizan una gran fiesta familiar en la que ofrecen el niño a la huaca y le ponen su nombre indígena ("llaman baptizalle otra vez": 215) que antepone al español y suele ser de alguna huaca o malquis. Al entrar en la pubertad tiene lugar un rito similar. También son de destacar los ritos funerarios (cf. 216, 226), el enterramiento en bóvedas (llamadas machays) para que la tierra no oprima a los que viven como difuntos y para poderles dejar comida, chicha y otros objetos queridos (cf. 220).

Los errores más comunes de los indios, ya nominalmente cristianos, tienen que ver con su origen y su fin. Al no haber oído nada de los primeros padres, creen en el poligenismo, no sólo en el sentido de que los españoles tienen un tronco y los negros otro, sino que están persuadidos de que cada ayllu tiene su pacarina (que puede ser un cerro, una fuente...), que es su creador, de quien cuentan mitos y a quien adoran y ofrecen sacrificios. Por eso insisten en permanecer en sus lugares, y cuando los reducen a otros pueblos regresan, si pueden, a sus pacarinas. Piensan que los que mueren van "a la tierra muda o de los mudos" (220) y que para llegar allí tienen que pasar un río por un puente estrechísimo. Aunque otros creen que las almas de los difuntos van donde están sus huacas. Como no conocen más bienaventuranza que tener buena chacra de que comer y beber, eso piensan que habrá en la otra vida y así desconocen tanto la gloria para los buenos como la pena para los malos. 


\subsection{Causas de la idolatría}

\section{a) La falta de enseñanza}

Para el autor, sin duda, la primera causa de la idolatría es la falta de enseñanza cristiana. Dice apenadísimo: "no me acuerdo que ninguno, por muchacho que fuese, me haya dejado de decir su huaca, y son bien pocos los que, preguntados quién es Dios y quién Jesucristo, lo sepan" (219). Nótese que escribe a los 89 años de haber llegado Pizarro a las playas de Túmbes. Lo que ocurre es que hay doctrinas que no ven al cura sino el día de la fiesta y el día de difuntos. Hay curas que no saben quechua. Otros sí saben la lengua, pero no saben predicar. Otros tienen capacidad para ello, pero no lo hacen. Son muchos los que no se preocupan de que los indígenas aprendan la doctrina, y ni ellos la dan ni supervisan al fiscal que se supone que la da. En muchos pueblos de indios los muchachos que mejor saben la cartilla se la leen o cantan a los otros muchachos todos los días y al pueblo los miércoles y viernes. Es frecuente que digan errores gruesos por no comprenderla. $\mathrm{Y}$ aun los que la saben bien, la saben "como papagayos, sin entender lo que dicen" (218). Hay curas que piensan que no conviene que los indios sepan leer ni escribir para que no les exijan ni les pongan pleitos. Incluso motejan a los que les enseñan el catecismo "diciendo que es impertinencia y que los indios no han menester saber teología, que éste es el término que oí a uno. Esta falta de doctrina es todo el daño" (219).

Siendo ésta la tónica, no se puede pensar que los indígenas tengan conocimiento ni estima de los sacramentos, sobre todo de la confesión y de la comunión, tan necesarios para que se afiance la vida cristiana, ni que participen en un culto que sea alternativa superadora de sus fiestas ancestrales. "Y siendo comúnmente los indios inclinados a la veneración y adoración de Dios, bien se deja entender cuán poca ayuda tienen en algunas partes para tener estima y conocimiento de la verdadera religión por la negligencia que hay en el ornato exterior de los templos y celebridad de los oficios divinos" (221).

\section{b) Permisividad religiosa y cultural}

Si la falta de doctrina y culto origina el que no se haya implementado la recta adoración a Dios, la pervivencia tolerada y aun querida del clima cultural y de las estructuras organizativas que están a la base del sistema religioso indígena, e incluso el permitir las mismas prácticas religiosas, explica por qué no sólo la idolatría no se ha desarraigado, sino que siga floreciendo, porque sus raíces de ningún modo han sido desgajadas de su tierra nutricia. Está, en primer lugar, la proliferación de ministros de la idolatría, y eso cuando tanto faltan los ministros cristianos. En todas las ocasiones los sacerdotes indígenas les siguen inculcando las cosas que ya habían aprendido con la leche materna y "que son conformes a su capacidad e inclinación", y en cambio las cristianas, "que son tan superiores a su entendimiento" (221), no tienen quien les enseñe. Además los 
curacas, pieza fundamental de la vida social indígena, ya que "ellos son el modelo de cuanto hacen" (222), se mueven con entera libertad para conservar sus tradiciones religiosas, practicarlas y transmitirlas. Por desconocimiento y falta de malicia de las autoridades españolas no se advirtió que continuaban practicando su religión, no sólo a los ojos de los españoles, sino incluso en el propio culto cristiano. Y así no les quitaron sus huacas móviles ni quemaron sus malquis ni destruyeron sus machays ni arrebataron sus conopas ni quemaron sus vestiduras e instrumentos musicales ceremoniales. No vieron malicia en los nombres indígenas que usaban por desconocer que eran de huacas o malquis. No repararon tampoco en los ídolos detrás de los altares, en las huacas o malquis debajo de las cruces, e incluso en las huacas en las andas de los santos que sacaban en procesión. No cayeron en la cuenta de que fiestas cristianas, como el Corpus, que aparentemente celebraban los indígenas con todo entusiasmo, eran en realidad sus fiestas ancestrales que correspondían a esas mismas fechas. Pero para Arriaga el mayor descuido estriba en disimular las borracheras y las juntas que se hacen para ellas, especialmente las mingas para hacer sus chacras o casas. "La unión de estas juntas es siempre el beber hasta caer, y de tal madre, demás de los incestos, estupros y otras muchas torpezas, ha procedido siempre la idolatría en los siglos pasados" (223).

Esta permisividad, para nuestro autor, no sólo ha sido la causa de que la idolatría siga prácticamente intocada, sino, sobre todo, ha impedido que los indígenas se percaten de la gravedad de su situación. "Que como es ordinario en gente de corto entendimiento conocer y estimar la culpa, no en ella ni por ella, sino por la pena" (223), al ver que no les han castigado, o muy poco, cuando les hallan en borracheras e idolatrías y que les castigan durísimamente por otras cosas, piensan que aquellas no son culpas o no son graves.

\section{c) Reinterpretación indígena del cristianismo}

Las dos causas expuestas hasta aquí las considera Arriaga externas, en cuanto tienen por sujetos a los españoles, mientras que los indígenas son sólo destinatarios. Pero expone otras dos causas que están en la conciencia de los indios. Por eso las cataloga como internas, y son para él tan perniciosas que piensa que son engaños del demonio y de sus ministros, con que tienen ciegos a todos los indios. La primera es pensar que el cristianismo es verdadero y bueno, pero para los españoles, del mismo modo que las imágenes cristianas son las huacas de los viracochas. Pero para ellos están bien las huacas, malquis y fiestas de sus antepasados. Se trata, pues, de una reinterpretación indígena de la religión cristiana. La segunda es todavía más grave, y consiste en que pueden adorar a sus huacas y a la vez tener a Dios por Padre, es decir, que es posible la práctica simultánea de ambas religiones. 


\subsection{Medidas para desarraigar la idolatría}

\section{a) Acabar con la permisividad e implantar eficazmente el cristianismo}

Los medios para desarraigar la idolatría que propone Arriaga corresponden al análisis que hizo de sus causas. Por una parte, hay que acabar con la permisividad y combatir por todos los medios la idolatría destruyendo su humus, que es el medio cultural del que la idolatría es expresión, y, por la otra, hay que implantar sistemáticamente la religión cristiana. Tomando los términos del profeta Jeremías, la tarea sería arrasar y plantar. El dispositivo que ha de poner en marcha este operativo de envergadura histórica sería la visita-misión que, en lo que tiene de visita, destruiría las huacas y todo lo relacionado con la idolatría, y, en lo que tiene de misión, pondría las bases de doctrina y de culto, y dejaría a las personas reconciliadas con Dios, listas para comenzar la nueva vida.

Pero este operativo resultaría inútil sin el concurso de los curas, ya que "el cuidado continuo del cura es lo que importa" (234). El es el verdadero sujeto en esta reevangelización indígena: "el único y principal remedio de este mal y la cura de esta enfermedad está en los curas y depende de su cuidado" (257). Pero si antes se dijo que en ellos estaba la principal causa de que los indigenas permanecieran prácticamente paganos ¿qué es lo que propone ahora para la transformación de los curas? Arriaga requiere el examen público obligatorio de predicación en lengua indígena, tanto para los opositores a doctrinas de indios, como para los que ya están en posesión de ellas, que serían destituidos si no muestran suficiencia. Como medida complementaria sugiere, para estimular el celo pastoral, premiar a los curas competentes y sacrificados con curatos mayores y de mejor temple. Pero en definitiva todo se reduce a exhortar a los curas a que se entreguen a su ministerio: para implantar el cristianismo lo que se necesita es la oración, el ejemplo y la doctrina. Respecto de esto último, la propuesta que hace es que se tengan sermones para el pueblo los días de fiesta, doctrina para todos, los miércoles y viernes, catecismos diarios para los muchachos y conversaciones espirituales. Los contenidos de los sermones deberian ser las cosas de la fe cristiana (contenidos imprescindibles, 244-45), la refutación de sus errores, las historias eclesiásticas y las vidas de santos "que gustan mucho de oillas" (258). Arriaga tiene conciencia de la necesidad de un contenido conceptual denso en la predicación indígena porque "no sé yo qué cosa hay mayor ni más profunda que los misterios de nuestra fe, ni más dificultoso que darles a entender de suerte que hagan concepto de ello los que tienen hecho el entendimiento a cosas tan materiales y rateras" (258). Por eso insiste en la necesidad de curas "doctos, especialmente en Teología. Porque es engaño muy grande decir y entender que no es menester para entre los indios Teología, que es frase y lenguaje que ha corrido mucho en el Pirú" (id.).

La solidez doctrinal deberá complementarse con la celebración de un culto 
digno, y aquí, de nuevo, el sujeto es el cura: "la falta del ornato de las iglesias más proviene de la falta de curiosidad de algunos curas que no de falta de plata" (236, cf. 258). Pero tampoco en este aspecto puede irse más allá de la exhortación.

También los curas serían los encargados de ejecutar las medidas represivas, aunque en esto el visitador les habrá aliviado de lo más sustancial y a ellos los tocaría velar por que se cumplan las constituciones que deja en la visita, entre las que las principales sería enviar a los principales maestros de idolatrías a la casa de reclusión de Santa Cruz, en el cercado de Lima, de cuya construcción y puesta en marcha fue encargado el propio Arriaga. Los que queden vivirán cerca del cura para que los vigile y serán obligados a sentarse en la iglesia con los niños y acudir con ellos todos los días a la doctrina "para que los vengan a tener en poco el común del pueblo" (238). Si reinciden, hay que castigarlos severamente, aunque, como la mayor parte son viejos y pobres, hay que socorrerlos con limosnas. Los curas tienen que examinar a los curanderos para que quiten de su oficio lo supersticioso y retengan lo que saben de yerbas y remedios. A los curacas los tienen que ganar honrándolos, aunque a los rebeldes que encubran la idolatria hay que destituirlos e incluso enviarlos a la mita o a la casa de Santa Cruz. Tienen que castigar a quienes reincidan en idolatrías, y para acabar con las borracheras se han dictado medidas muy severas, "¿pero quién lo ejecutará?" (240).

Como medida a largo plazo para crear una alternativa cultural cristiana que mantenga las estructuras organizativas indígenas Arriaga propone la aculturación de los hijos de caciques en colegios especiales (Lima, Cuzco y Charcas) para que "desde muchachos aprendan la política y religión cristiana. Sus padres estiman la merced que en esto se les hace" (239).

\section{b) La visita}

"Pero el primero y más próximo y más eficaz remedio y que ha de ser ejecutor de todos los demás, es esta primera visita" (240). Por eso Arriaga se extiende en explicar cómo hay que llevarla a la práctica, ya que está convencido de que el método de Avendaño y Avila y los misioneros jesuitas, largamente experimentado y a su juicio con fruto, debe servir de paradigma.

Respecto del visitador insiste en que debe conocer la lengua, ser teólogo y tener talento para predicar. Ha de recibir paga conveniente para que no pida ni reciba nada, ni él ni sus criados, que por eso deben ser los menos posibles, aunque no pueden faltar el fiscal ni el notario. $\mathrm{Ha}$ de ir con religiosos que catequicen, prediquen y confiesen, pues aunque hay jesuitas que piensan que el visitador y los misioneros deben separarse, la experiencia confirma que se complementan "concurriendo como dos causas parciales a un mismo efecto" (243). A los padres les ayuda la obligación que pone el visitador al pueblo de asistir a 
los actos religiosos, y a éste los padres le ayudan para ablandar los corazones y dar el tono a la visita, quee es "más de misericordia que de justicia" (242).

Sugiere no comenzar la visita por el centro poblado, sino por los ayllus más lejanos, a ser posible contiguos a zonas ya visitadas. También recomienda tener averiguado algún rastro de idolatría del lugar para, por ese cabo, sacar el ovillo. Hay que avisar de antemano para que en el pueblo se junten los indígenas a recibirlo. En llegando, el visitador proclama el edicto de la visita y enseña las provisiones del virrey y del arzobispo para que quede claro que viene con toda autoridad de ambos. A continuación explica el objetivo y la mecánica de la visita y recalca que ésta durará hasta que logre su propósito e insiste en su espíritu, que no es castigar, sino desengañar y reconciliar. Y por eso no habrá castigos a los idólatras que reconozcan su culpa; pero sí se castigará a los que oculten lo que saben y a los recalcitrantes.

La pesquisa de las idolatrías se lleva a cabo en dos fases complementarias: investigación extrajudicial y declaración jurada. La primera comienza con absoluto sigilo, de modo que los informantes son prácticamente secuestrados sin testigos y mantenidos incomunicados durante días. Son elegidos para este fin ancianos, curacas, curanderos e indios de razón. La primera pregunta parece inocente: cuáles eran las huacas del pueblo antes de los españoles, y tienen que saber las respuestas porque o vivieron en ese tiempo o se lo contaron sus padres. Si no hay respuestas, se alternan la soledad con los interrogatorios y las amenazas con los halagos. De esta pregunta se pasa a indagar por las huacas móviles, que antes se adoraban, ya que nunca fueron recogidos; y finalmente se llega a lo que se adora en el presente, sus ministros y sus fieles. En estos interrogatorios se tienen apostados testigos ocultos para que no se desdigan al ser careados con los denunciados. Una vez puesto en claro que hay idolatrías, se procede a un interrogatorio extensísimo ( $c f .248-50$ ) a los personajes antes mencionados y a los sacerdotes ya reconocidos como tales. El interrogatorio es aún extrasumarial, pero ya no clandestino; se trata de una declaración de informantes voluntarios, aunque en realidad es un examen que el visitador hace, a solas, a las personas que más saben del asunto y de todos los sacerdotes indígenas para hacerse un cuadro del estado actual de la idolatría en esa comunidad. Sólo entonces tiene lugar la declaración oficial que se hace en la iglesia, solemnemente, en presencia de uno de los padres. Acude cadaayllu y son llamados a presencia del visitador uno a uno, por padrón a acusarse de las propias idolatrías, que son escritas en un libro de "Acusaciones". Por este examen han de pasar todos, incluso los que rindieron antes declaraciones, y también los muchachos, aunque para ellos el interrogatorio es más sumario. Al acabar cada sesión, los acusados se arrodillan a la puerta de la iglesia y el visitador les manifiesta "cómo hasta ahora han sido hijos del demonio y han estado en pecado, que es necesario que se conviertan de corazón a Dios" (253), jurando solemnemente que nunca abandonarán la fe. Después los golpea con varas y les levanta la excomunión. Acaba advirtién- 
doles que todavía no les han perdonado el pecado y que para eso tienen que confesarse.

Mientras así se desarrollan las pesquisas y acusaciones, el pueblo sigue un ritmo especial que da el ambiente a la visita. Todos vienen muy de mañana para la misa, la doctrina y el sermón, y si el clima lo permite vienen en procesión cantando la doctrina. Luego se quedan sólo aquellos a los que el visitador ha de examinar sobre las idolatrías y aquellos a los que los padres han de dar doctrina o confesar. Hay que notar que la confesión tiene que constar obligatoriamente en el padrón, y para ser recibidos en confesión tienen que llevar un recibo de suficiencia en la doctrina. Al comienzo de la tarde viene el ayllu para lo mismo. Hacia la puesta del sol regresa todo el pueblo para el catecismo. Los miércoles y viernes, los varones se quedan para darse disciplina.

Acabadas las acusaciones se mandan a traer las huacas y malquis, y los acompaña, para cerciorarse de que todo se encuentra como consta en la declaración. Seguidamente tienen lugar las "exhibiciones". Cada quien comparece por padrón para entregar lo relacionado con la idolatría, todo lo cual se vuelve a inventariar, cerciorándose de que no falte nada de lo que fue declarado. Después los sacerdotes indígenas traen las huacas y malquis y sus adminículos. Hecha una pira, se quema todo y la ceniza se esparce secretamente en los ríos. Los objetos de plata se pesan públicamente y se entregan a las autoridades, para que conste públicamente que ellos no se quedan con nada. Luego se reúne a los "hechiceros" y se les condena a andar con una cruz de madera al cuello y a acudir con los niños a la doctrina diaria.

Se finaliza todo con la solemne fiesta de la Cruz. Todo el pueblo reunido, y los "hechiceros" con vestidos infamantes, van a misa en procesión llevando una gran cruz. Después del sermón, los sacerdotes principales se acusan ante el pueblo y manifiestan su enmienda. Sigue otra procesión y todo acaba con la lectura y explicación de las constituciones que dejan en el pueblo para remedio de la idolatría.

"No se puede decir (concluye Arriaga), sino se ve y experimenta, el consuelo y contento con que quedan los indios acabada la visita; no tanto porque se vaya el visitador, cuanto de conocer sus engaños y de quedar enseñados y confesados" (256), aunque reconoce que muchos sacerdotes indígenas, al verse afrentados, perdido el crédito y las fuentes de sus ganancias y, sobre todo, ajenos al cristianismo y connaturalizados al amor de sus huacas, son fáciles de volver a sus errores y arrastrar a muchos a ellos. "Pero si es grande el contento con que quedan los indios, mayor es el que llevan los que les enseñaron y confesaron viendo cuán diferente queda aquel pueblo de lo que le hallaron, encaminado a la vida eterna" (id.). 


\section{Discusión sobre el planteamiento religioso de Arriaga}

\subsection{Una religión agraria}

\section{a) Religación a la tierra y a la comunidad}

Prescindiendo de la cuestión de si el autor captó con exactitud la religión indígena, aparece claro de su descripción que él se encontró con una religión agraria. Las huacas fijas son elementos de la naturaleza: el sol, la luna y algunas estrellas, como las pléyades, están asociadas al ciclo agrario, así como el rayo es tenido como el creador de la lluvia. La Pachamama es la tierra fértil. Los Puquios son los arroyos, tan necesarios para el riego. Los Apus, las montañas, son los señores llenos de magnificiencia y protectores. Todos ellos son sus Pacarinas, sus progenitores, y por lo tanto los indígenas no son sólo "terrenos, los de la tierra" (Adam adamá), sino naturales de una tierra determinada, de un cerro concreto, de este manantial... De esta forma, la veneración es también comunión, es decir, relación entrañable de pertenencia entre el hacedor y sus criaturas, entre la madre y sus hijos. Las huacas móviles son "imágenes y representación" de los elementos de la naturaleza. Así, la relación con ellas sacramentaliza la relación concreta con la tierra concreta, es decir, personaliza hasta el detalle, tanto a la naturaleza como a la relación con ella.

El por qué de esta extremada particularización aparece al considerar que los malquis, los cuerpos de los antepasados, son hijos de las huacas, es decir, que cada comunidad es creatura de una tierra concreta que le sirve de recinto, sustentáculo, alimento y vida. Pero tambiér la comunidad hace valer a esa tierra, la ayuda, con su licencia, a producir. En este sentido, la relación es mutua: la tierra se complace con sus hijos (eso significaría que las huacas piden que sus hijos no las olviden) y las creaturas acuden pidiendo bienes y agradeciendo a la fuente de su vida (ése sería el sentido de adorar a las huacas). Y el desdoblamiento de huacas y malquis expresaría que es la comunidad histórica la que es hija de huacas y pacarinas, la que - por concesión de esta naturaleza concreta- la ha puesto a producir y vive de ella y en ella. De ahí que el individuo es concretamente natural, es decir, encuentra su vida y su sacralidad, no en su condición de sujeto individual, sino como miembro de una comunidad concreta. Por eso, las fiestas, que expresan simultáneamente la comunión con la naturaleza y la comunidad como sujeto adecuado de esta comunión, van precedidas de la confesión en la que cada individuo revisa las deficiencias en su relación con la comunidad (haraganería, robo, maltrato, adulterio, desobediencia al curaca) y rehace su plena lealtad con ella para así participar en ella de la comunión sagrada y gozosa con las fuerzas de la vida.

Por otra parte, lo que es irreductiblemente individual no encuentra lugar en esta religión. Así, la enfermedad que ocurre en la plenitud del ciclo vital no 
puede verse sino como malquerencia de estas fuerzas, a las que se pretende exorcizar con la confesión y las ofrendas. Y si la enfermedad no es sanada por yerbas, en este contexto sagrado, queda como un misterio que llena de desconsuelo. De igual manera, las decisiones individuales, al no tener cabida en este marco, son procesadas mediante la adivinación, lo cual no es fácil de relacionar con esta forma de sacralidad.

\section{b) Sentido de las fiestas}

Las fiestas, tal como el autor las describe, están todas ligadas al rito agrario y serían la expresión privilegiada de esta religión. El presupuesto de la fiesta es la existencia de buena cantidad de excedentes, lo que sería índice de que funcionaba muy bien el sacrum comercium, es decir, el intercambio sagrado de dones en lo que consiste la vida de la comunidad. El trabajo es sagrado en cuanto realiza la reverente toma de posesión de la tierra por parte de la comunidad, y su fruto expresa que la tierra acepta a sus creaturas. Pero el trabajo no sólo sirve para la vida de todos los días. El fruto del trabajo es, sobre todo, para ser consumido en la fiesta, así como la vida cotidiana logra su consumación. Por eso, la fiesta es algo que se prepara, no sólo en sus elementos organizativos, sino para que cada individuo de la comunidad y la comunidad como un todo se dispongan para ella. El ayuno, la abstinencia sexual y la confesión están encaminados a alcanzar la limpidez y la armonía que deben caracterizar a un hijo de esa tierra, a que cada quien y la comunidad sea lo que es, a que se asuma como digno de esa tierra. A eso ayudan los cuentos y los mitos, que se refrescan en esos días.

Llega la fiesta y ésta se convierte, a través de la huaca, en comunión con la naturaleza y en comunión con la comunidad. Las vestiduras rituales expresan la existencia resplandeciente. La música, el canto y la danza, acompañados de invocaciones sagradas, junto con la chicha, fruto también de la tierra, son los componentes de la existencia extática. La comunidad se trasciende en el exceso, participa de la alegría y el juego, que son propios de la naturaleza, por la sobreabundancia de sus encrgías, y evoca y se funde con sus poderes fecundantes, productores de vida.

Las ofrendas a la huaca, pidiéndole salud, vida y buenas chacras, serían el lazo entre la cotidianidad y la fiesta: en ésta la vida se hace libre y sagrada, y por eso en la fiesta se acaba con los excedentes. La petición ante la huaca expresa la confianza en la divinidad, es decir, que la fe que se expresa en la fiesta sea fuente de vida y que la divinidad dé vida para llegar de nuevo a unirse con ella en la fiesta. Aquí se ve claramente que las buenas chacras y la salud son para la vida, que llega a su consumación, sobre todo, en la comunión sagrada de la fiesta. La fiesta, pues, expresa la victoria de la comunidad sobre la necesidad, y -al consumir los excedentes- expresa la confianza en que esa victoria volverá a alcanzarse siempre con el favor de los dioses por mediación del trabajo. 
Expresa, pues, la libertad y la trascendencia de la comunidad, aunque esa libertad no consiste en salirse de la naturaleza, sino en participar de sus energías sobreabundantes que van mucho más allá de lo meramente funcional. De ahí, la música, el baile y el canto interminables, y también la bebida en la que el exceso llega a su consumación y que pone fin a la fiesta.

c) ¿Religión materialista?

Si este es el sentido de la fiesta, hay que matizar la valoración que hace el autor de la religión indígena, a la que tacha de materialista: "no conocen en esta vida ni en la otra más bienaventuranza que tener buena chacra de que pueden comer y beber" (220). A la huaca o malquis "le piden que les dé salud y vida y de comer, etc. Y no piden cosa ninguna para la otra vida" (213). "Las invocan y adoran como a sus hacedores y de quien esperan todo su bien y felicidad; digo la temporal y visible, porque de la espiritual y eterna, como tienen poco o ningún aprecio, ni la esperan ni lo piden comúnmente" (196).

La contraposición entre vida temporal y visible, y vida espiritual y eterna, no hace justicia a la religión de la tierra. Los patriarcas y Moisés, los reyes David, Ezequías y Josías, y también los profetas pensaron, como los indígenas, que después de la muerte se entraba en una existencia umbrátil, y no por eso su religión dejó de ser espiritual. La promesa de Dios a Moisés consistió en una tierra que manaba leche y miel, y no por eso Yahvé es un Dios materialista. Los patriarcas ligaron su experiencia de Dios a lugares concretísimos, como el encinar de Mambré, donde levantaron altares y estelas, y para ellos los signos del favor de Dios consistieron en vida larga, protección de los enemigos, descendencia numerosa, abundancia de ganados y frutos de la tierra, y ni su religión era por eso falsa ni su Dios era otro que nuestro Dios. Las bendiciones de Jacob (que con el nombre de Israel podríamos considerar como el malquis, el ascendiente epónimo, del pueblo de Israel) a sus hijos (que son en realidad las tribus de Israel) no son de índole distinta a las bendiciones a que los indígenas aspiraban y sus huacas y malquis les otorgaban. Estas son, por ejemplo, las bendiciones de Jacob a algunos de sus hijos. Dice de Judá: "Ata su burro a una viña, las crías a un majuelo / lava su ropa en vino y su túnica en sangre de uvas" (Gn 49, 11). "Isacar es un burro robusto que se tumba entre las alforjas / viendo que es bueno el establo y que es hermosa la tierra / inclina el lomo a la carga y acepta trabajos de esclavo" (id. 14-15). Y así bendice a José: "El Dios de tu padre te auxilia, el Todopoderoso te bendice / bendiciones que bajan del cielo / bendiciones del océano acostado en lo hondo / bendiciones de pechos y ubres / bendiciones de espigas abundantes / bendiciones de cerros antiguos / bendiciones de colinas perdurables" (id. 25-26). Pablo ante los atenienses caracteriza a Dios como "el que a todos da la vida y el aliento y todo" (Hch 17, 25); y a los paganos de Listra les dice que Dios "en las pasadas edades dejó que cada pueblo siguiera su camino, aunque siempre se dio a conocer por sus beneficios, man- 
dándoles desde el cielo estaciones fértiles, lluvia y cosechas, dándoles comida y alegría en abundancia" (Hch 13, 17). Así, pues, estos beneficios ni son indignos o impropios de Dios, ni pedirlos o recibirlos es señal de la falsedad de una religión.

Ya mostramos que la fiesta expresa una relativa libertad y en ese sentido manifiesta espíritu, y que esa libertad está fundada no sólo en el trabajo productivo, sino en la confianza en la divinidad y, en ese sentido, expresa trascendencia. Esta también se echa de ver en el contenido de las confesiones, ya que el reconocer los pecados propios, que restan vida a la comunidad y a sí mismos, responsabilizándose de ellos y prometiendo enmienda, es signo de que la vida a que se aspira es una vida digna. Si se acusan de robo o de maltrato o de adulterio o de trabajar poco es porque vivir no es simplemente seguir el gusto, la gana, la comodidad o el interés; es vivir de modo que no se quite vida a otros y que se contribuya a la vida del conjunto. Esta vida, cristianamente hablando, es vida espiritual, ya que espiritual se contrapone a egoísta, y, como tal, a lo cerrado a Dios, lo intrascendente.

\section{d) Las borracheras}

Un punto delicado a juzgar son las borracheras. Es cierta la observación del autor de que son un elemento de las prácticas de comunión de muchas religiones y ciertamente de las religiones agrarias. Hay que reconocer que la borrachera es proclive a la degradación humana y que puede propiciar no sólo la promiscuidad sexual, de lo que acusa el autor, sino violencias que originan enemistades y muertes. Es un punto crucial de desencuentro entre indígenas y misioneros, y actualmente sigue siendo un problema agudo.

Por otra parte, la borrachera de los indígenas no suele ser juzgada con frecuencia desde un punto de vista lo suficientemente integral, de modo que pueda identificarse con la tradición cristiana, y ciertamente no puede remontarse a Jesús de Nazaret, quien, por su parte, participaba frecuentemente de banquetes, comparaba el reino de Dios a un banquete espléndido, fue acusado por sus enemigos incluso de comilón y borracho, y, según el evangelio de Juan, comenzó su misión convirtiendo una enorme cantidad de agua en vino en un banquete de bodas, cuando todos estaban borrachos, para que pudiera seguir la fiesta. De ningún modo estoy afirmando que Jesús fuera un borracho, pero sí es cierto que distaba tanto de ellos como de los ascetas fariseos o del círculo de Juan o del fariseo Pablo y del ascetismo usual en el cristianismo.

Da la impresión de que el autor -en consonancia con el ascetismo convencional cristiano - tiende a juzgar la borrachera desde su contrario, es decir, la abstinencia o morigeración, pero no desde su contradictorio, lo realmente superador, tal como lo practicó Jesús. Desde el fariseísmo cristiano, que se afinca en la fuerza de voluntad para controlarse y mantener dominio. de sí, el debilitamiento de la censura, la desinhibición, es muy peligrosa y la pérdida de 
la conciencia causa pavor porque se teme que lo reprimido se alzará y se seguirá la catástrofe. El fariseísmo cristiano no es capaz de lograr la sanación de las pulsiones atadas a circuitos infantiles o destructivos ni la transfiguración personal, y ni siquiera alcanza a concebirla y a ponerse discretamente en camino hacia ella. Por eso descalifica a lo que es su extremo opuesto, pero lo hace desde su alienación, aunque no reconocida. Es el mecanismo del resentimiento. Sólo desde el reconocimiento, sin embargo, de la insuficiencia de una postura que es incapaz de vivenciar la alegría y vive asechada por el malestar, puede comprenderse también la insuficiencia de la postura contraria sin anatematizarla. ¿Cabe una borrachera colectiva en la que el espacio-tiempo ritual, con la preparación que le precede, pueda minimizar los efectos indeseables y expresar meramente el éxtasis? Las borracheras a que se refiere Arriaga, ¿no están ya descritas desde las sospechas de los curas, y degradadas y envilecidas al ser de algún modo ya la realización de lo que ellos prohibían? ¿Serían así las borracheras precristianas de los indígenas, hechas, si así puede decirse, con entera buena fe? Nos inclinamos a pensar que sí hubo fiestas así, aunque periódicamente habría que redimirlas de la decadencia inevitable. De todos modos, desde el paradigma de Jesús, que para nosotros es el criterio decisivo, no parece, por una parte, que haya lugar en las fiestas "al beber hasta caer" pero por otra, tampoco hay lugar para la seria rigidez vigilante del fariseo cristiano, que es incapaz de entregarse a la alegría de la fiesta, que minimiza su valor en su propia vida y en la vida de la comunidad, que se escandaliza de las fiestas populares y que no se sabe que hará en el banquete del reino.

Este asunto es muy significativo. Los visitadores, los misioneros y los curas responsables podían presidir algunos momentos de la "fiesta" cristiana. Pero, a causa de su burdo fariseísmo, no se entregaban a lo propiamente festivo de la fiesta. Este es un punto crucial de desencuentro entre estas nuevas autoridades y el pueblo, cosa que no sucedía con los curacas y sacerdotes indígenas. Al no entregarse a la fiesta, al no consumir en ella sus energías, al inhibir esa experiencia fundamental de vida en comunión con la comunidad y la naturaleza, estas nuevas autoridades transformaban ese ahorro de energías en distancia vigilante y, finalmente, en dominio sobre los que vivian la experiencia.

El juicio religioso y moral que hacen sobre ellos y la mala conciencia que les introyectan son un modo de ejercer el poder que genera esa abstinencia. Si llamamos conducta a las pautas que se imponen desde fuera y experiencia a la vivencia desde las profundidades de la propia existencia, tenemos que concluir que el misionero, a fuer de fariseo cristiano, desde su conciencia y voluntad, impone conductas al resto de su ser y, desde su retracción vigilante de la experiencia, impone conductas a los demás. Se trata, pues, de un ejercicio de poder externo que tiende a sustituir la experiencia por conductas pautadas, en sí mismo y en los demás. El triunfo de esta tendencia produce una sociedad altamente disciplinada, incluso eficiente, pero sin comunión y separada de las más 
primigenias fuerzas vitales. Además instaura la dicotomía entre dirigentes y dirigidos, entre controladores y controlados. Esta distancia no se convierte en abierto despotismo porque, en este caso, los dirigentes desean sinceramente el bien de sus ovejas y no tienen pretensiones de poder o de provecho personal, sino que trabajan con todas sus fuerzas por la causa, aunque lo hagan desde una alienación de la que son víctimas inconscientes. Por eso son queridos y temidos a la vez, y de un modo inextricable causan bienes y estragos. Mientras tanto, los malos curas doctrineros hacen pagar a sus indios pesados peajes; pero, por su falta de preocupación profunda, dejan espacios desocupados, libres de pautas y vigilancia, y así permiten que la experiencia, que es el alma de la comunidad, siga funcionando, incluso incorporando desde sí misma elementos del propio cristianismo.

\section{2 ¿Adoración o veneración?}

Desde nuestra perspectiva, la pregunta para discernir la verdad de este tipo de religión es si adoraban o veneraban a las huacas. Aunque el autor utilice ambas expresiones es obvio que las usa como sinónimas, ya que para él los indígenas "adoraban como a Dios" (202) a la huaca y cuando la invocan "la llaman Runapcamac o criador del hombre y otros nombres semejantes debidos a solo Dios" (213). De las huacas móviles dice, sin embargo, que "no hay que admirarse que en cosas tan pequeñas reconociesen deidad los indios" (196) porque "son imágenes y representación" (id.) de las huacas fijas. La pregunta es si para los indígenas éstas eran dioses propiamente dichos o si reconocían en ellos "deidad", porque eran "imágenes y representación" de lo divino. En este segundo caso se trataría de la noción de la naturaleza a la que, según el primer capítulo del Génesis, Dios habría dado poder para producir todo género de vida. Este poder es dado por Dios y es por eso un poder sagrado, y quien recibe ese poder es, concíbaselo como sea, un sujeto. De ahí la sacralidad de la naturaleza y la pertinencia de venerarla. Si una comunidad local desbravó y cultivó con mucho esfuerzo y a través de generaciones una tierra muy particular, particularizándola más con su trabajo, es normal que le dé culto, que cultive, también religiosamente, a esa tierra concreta, que es la representación, refractada en diversas imágenes, de lo divino, ya que sólo a través de esos canales fijos se manifiesta la acción creadora y vivificante de Dios.

De modo equivalente podemos preguntarnos si los indígenas consideraban que provenían de sus pacarinas en el sentido de que la divinidad creadora los "sembró" en ellas y por eso brotaron de ellas o en el sentido de que eran sus progenitores propiamente dichos. Si se tratara de lo primero es una manera simbólica de decir que, como comunidad, como seres culturales, han brotado de esa relación entranable con esa tierra concreta en la que reconocen la primacía que tiene la acogida de la tierra. 
Tal vez esta religión agraria indígena (a la que debemos distinguir de la religión imperial, y por lo tanto política, de los incas) no estaba en condiciones de responder si adoraba o veneraba a la naturaleza, porque se mantenía en un estado de fluidez, de indeterminación real. Es decir, no se trata de que los indígenas no querían hacerse cargo de lo que realmente hacían o que no tuvieran capacidad de reflexionar sobre ello, sino de que sus concepciones y prácticas religiosas eran realmente ambivalentes. Si esto es así, nos tenemos que preguntar si no fueron los misioneros quienes los hicieron idólatras, y, sobre todo, si no lo fueron los extirpadores de idolatrías al pretender decantar arbitrariamente hacia la idolatría lo que en realidad se mantenía en un estado indefinido y, por lo tanto, abierto. ¿Internalizarían, al fin y al cabo, los indígenas esa interpretación de los misioneros afincándose, con mala conciencia, en lo suyo así reinterpretado? Puede ser que así haya sucedido con algunos dirigentes. Pensamos que la mayoría siguió simplemente con lo suyo, que esto fue evolucionando desde dentro, incorporando elementos cristianos y asumiendo la reinterpretación cristiana en el sentido de que su veneración religiosa ancestral se dirigía en resumidas cuentas, a Dios.

\section{3 ¿Invento diabólico?}

\section{a) ¿Conforme a su capacidad y/o causada por el diablo?}

Sea como sea, hay que destacar que Arriaga reconoce la adecuación entre esta religión y la índole de los indígenas: se trataría de un sistema religioso "conforme a su capacidad e inclinación" (221). Aunque fueran errores, si son "errores tan connaturalizados a su capacidad" (241), podría pensarse que, si no tienen por autor a Dios, son elaboraciones nacidas de su propia cultura. Por eso, aunque a veces se refiere al temor que inspiran las huacas (el tremendum de lo santo que diría R. Otto) es más frecuente que destaque el amor, y así habla de "sus amadas huacas" (233), comenta "el amor tiernísimo que han tenido a sus huacas, el cuidado con que las han guardado y el dolor grande si se las quitan" (231). Refiriéndose, sobre todo, a los sacerdotes de las huacas, comenta: "tienen (...) embebido y connaturalizado el amor de sus huacas, de sus idolatrías, supersticiones y ceremonias" (256; $c f .261)$. Ese cuidado solícito aparece señaladamente en todo lo que se refiere al ciclo agrario y explota en reconocimiento alegre en la fiesta. Más aún, si insiste en que la idolatría sólo se desarraiga a través de generaciones por ser "raíces tan arraigadas y antiguas" (201) y afirma que "quien hubiere leído las historias eclesiásticas del principio y discurso de la Iglesia" (195) no se asombraría de que "mal tan antiguo y tan arraigado y connaturalizado con los indios no se haya del todo desarraigado" (id.), parecería estar pensando en una elaboración cultural prolongada y coherente.

Por eso, no deja de ser sorprendente que Arrriaga atribuya todo esta religión al demonio. Porque ¿cuáles serían esos elementos demoníacos? ¿Dónde estaría 
en ella la marca del enemigo de la naturaleza humana? Al demonio se lo liga con la ofuscación de juicio y con la mentira; con la deshumanización (conversión en fieras sanguinarias y bestias degradadas); con la desunión, las enemistades, la cizaña, la ruptura de la comunidad (ese sería el sentido literal de lo diábolico frente a lo simbólico); y con la muerte. Los cultos demoníacos eran considerados como la inversión de la recta adoración y se asociaban a aberraciones sexuales y derramamiento de sangre, además de la adoración formal a Satanás bajo figuras animalescas de catadura siniestra. ¿Hay algo de esto en esta religión agraria, tal como la percibe Arriaga? Analicemos, pues, su demonología.

Es indudable que Arriaga piensa que la religión indígena es un invento diabólico: "los demonios por hacer mal a los hombres y vengarse de Dios inventaron las huacas y las demás supersticiones" (244). La conclusión de esta premisa es que, lo sepan o no, al entregarse a su religión, los indígenas se entregan al demonio, pasan a su poder. Por eso el libro está concebido como un arbitrio que muestra "cómo se rescatarán tantas almas que están en dura esclavitud del demonio" (193). La pieza central de este arbitrio, la visita, está dirigida consecuentemente a "sacalles de la ceguedad en que el demonio los tiene" (247). Por eso, al que en los interrogatorios niegue saber qué idolatrías hay en el pueblo "se le dirá que el demonio le endurece el corazón para que no confiese su pecado y vaya al cielo" (247). Y por eso, cuando ya se haya descubierto todo, el visitador, con graves palabras debe advertirles "cómo hasta ahora han sido hijos del demonio y han estado en pecado, y que es necesario que se conviertan de corazón a Dios" (253). Esta es la razón por la que califica a la campaña de extirpación de idolatrías de "batalla espiritual contra el demonio" (272). E insiste en la fortaleza que deben tener los que se meten a ella para no desmayar por "los estorbos que el demonio ponga para que no le desencastillen de la posesión que ha tenido tiranizada tantos años" (272).

La pregunta es ¿por qué atribuir al demonio lo que puede explicarse como expresión simbólica, como sacralización de una cultura? Si esa religión es tan adecuada a su propia índole podría pensarse que ambas son resultado de una cultura, más concretamente, de la centralidad del ciclo agrario para la vida de la colectividad, y del entrañamiento secular de la comunidad en un terruño, convertido en querencia a través del trabajo de muchas generaciones a las que la comunidad se siente ligada y agradecida. Más aún, ¿no es lícito pensar que en esa historia hay sacralidad y que, por lo tanto, las prácticas religiosas son un intento para expresar esa presencia vivificante de Dios, la religación con las fuerzas creadoras de esa vida concretísima, tan laboriosamente alcanzada y tan apasionadamente vivida?

b) ¿Trazos diabólicos?

Ahora bien, si una comunidad humana se encuentra en un estado de degrada- 
ción y perversión tal que ha perdido su dignidad e incluso su condición humana en algunos aspectos esenciales, a la cultura religiosa que la expresa, que la mantiene en ese estado y lo refuerza, no podríamos llamarla sagrada, no tendría su origen ni en Dios ni en lo más genuino de la condición humana tal como salió de sus manos. En este caso se trataría del enemigo que sembró mala simiente en ese campo. ¿Es este el caso de los indígenas? Tal vez así lo creían algunos curas doctrineros, cuyas cartas incluye Arriaga. Escribe uno de ellos : "Era compasión ver esta doctrina y gente indigna de este nombre, pues más parecían bestias y salvajes, faltos de toda cosa buena" (235). Y otro expresa su deseo de que "ablanden los corazones, que tan duros tienen para lo bueno" (237).

Ahora bien, fuera de estos juicios tan negativos y, por otra parte, tan sumarios, ¿cuáles serían en concreto, según la visión de Arriaga, esos pecados tan deshumanizadores, generalizados y connaturalizados? Fuera de la fomicación simple entre solteros y la borrachera en las fiestas y en las mingas, el autor no reseña ningún otro, y éstos no parecen conformar una situación deshumanizante. Así, pues, para el autor el engaño del diablo es fundamentalmente religioso: hacerles creer que las huacas, tanto las de la naturaleza, como las móviles que les representan, son dioses y deben recibir adoración. Así lo escribe un cura doctrinero acerca de las huacas: "el respeto, el amor y el temor que el demonio les ha puesto de ellas me admira" (231). Más aún, si las huacas —que son seres inanimados- hablan, es que el diablo habla a través de ellas $(c f .203,205,218)$. Esta sería una presencia más explícita del demonio ( $c f .196,205,207)$. Por eso, en la visita una de las preguntas que se hacía al sacerdote indígena era - si se volvía loco cuando iba a hablar con la huaca - que aclarara "si era por la chicha que bebía o por efecto de demonio" (250). Sin embargo, ni aun en este caso las respuestas del demonio irían más allá de predecir sucesos de la vida o de las cosas de su religión. Tampoco en esa respuesta se notaría, fuera del engaño de hacer creer que viene de Dios lo que nace de él, la huella deshumanziadora del "enemigo de natura humana". Entonces, reiteramos la pregunta: ¿por qué meter en esto al demonio si todo se explica sin él y si él no deja huellas de lo que suele entenderse como actuación suya?

\section{c) Religión demoníaca y religión agraria}

La pregunta es tanto más pertinente cuanto Arriaga conoce otras manifestaciones religiosas en las que sí está presente lo que hemos caracterizado como demoníaco. En efecto, cuando trata de los ministros de la idolatría menciona a aquellos que merecen más propiamente el nombre de hechiceros, que son los que "comen hombres" ( $c f$. 207-9). A estos, dice, en sus juntas nocturnas se les aparece el diablo en forma de león o de tigre furioso, y lo adoran. "De las tres cosas que son ordinarias en los brujos, que son crueldades, idolatrías y torpezas, de las dos primeras descubrieron mucho, de la tercera poco" (208). Así, pues, 
Arriaga entiende lo diabólico tal como lo hacemos nosotros, y a la vez reconoce que estos hechiceros, muy temidos por los indígenas, no son propios de la sierra -al menos de lo que él conoce y sabe del territorio del arzobispado- y que donde se hacen presentes son heterogéneos en relación a la religión agraria que él caracteriza, y por eso no hace mención de ellos al tratar de las huacas o de las ofrendas y sacrificios o de las fiestas. Esta heterogeneidad es la razón de por qué el cuestionario de las visitas reserve para estos hechiceros preguntas especiales: "si hablan con el demonio y en qué figura se le aparece" (249). Y en el edicto se inquiere: "si saben que haya en este pueblo alguno o algunos indios que sean brujos maléficos o tengan algún pacto con el demonio" (274). Esta heterogeneidad se confirma en una carta, escrita por el padre Turuel, compañero suyo en la visita en que escribió este tratado, que transcribe el autor: "Ahora que he visto por mis ojos lo de por acá, hallo que los indios del arzobispado de Lima, que tanto ruido han causado, son unos santos. Porque aunque las huacas y hechiceros que allá se han descubierto han sido sin número, han sido muy raros los que han tenido trato formal y expreso con el demonio, y las ofrendas son de yerbas y cosas de burla. Porque acá, mi Padre, hay tan gran número de demonios, súcubos e íncubos y tan familiar trato de los indios con ellos que ya no les tienen miedo más que unos indios a otros (...) muy ordinario uso de sacrificar a las huacas niños, los cuales escogen en todo el pueblo que no tengan mancha" (266).

Como se ve, la diferencia de ambas religiones es tajante. La religión agraria es, digamos, sana: las oraciones, las ofrendas y los ritos de comunión tienen que ver con la salud, la vida y la fecundidad de la tierra. Los devotos ofrecen de lo que la misma divinidad les propicia, dan de su trabajo y celebran su vida, que es la de la comunidad y la de la tierra. En ese sentido "son unos santos" ya que tratan sobre cosas santas como son la salud, la vida y la fecundidad, dones en definitiva del Espíritu dador de vida, aunque esto lo hagan mediante simulacros que puedan parecer infantiles y "cosas de burla" a quien piensa que ha llegado a la madurez del conocimiento y la adoración. Pero, en cualquier caso la relación sería entre lo infantil y lo adulto, o, como dice Guamán, de "sombra" de conocimiento al conocimiento cabal. Los hechiceros y brujos, por su parte, no celebran la vida humana, sino que actúan en el secreto de la noche, quebrando la comunidad, violando la vida y la dignidad, tanto de ellos como de sus víctimas. En los ritos agrarios comunican con sus divinidades los elementos de su vida; en estos ritos fetichistas los sacerdotes no se ofrecen a sí mismos, sino que convierten en víctimas a otros. Sea lo que sea de la realidad del demonio, sí podemos llamar demoníacas a estas prácticas religiosas, a esta religación negativa con las fuerzas del mal, a esta entrega a ellas para el envilecimiento propio y el mal ajeno. Y, según lo dicho, quedaría establecida en el texto la diferencia entre una religión que es engaño del demonio y otra que es formalmente demoníaca. Si es correcta esta distinción, ¿no sería abusivo decir que los indígenas están en poder y en 
manos del demonio, y más aún que son sus hijos? Más todavía, nos preguntamos de nuevo, ¿por qué atribuir a engaño del demonio la religión indígena agraria?

\section{d) Causas de la atribución demoníaca}

Esto, creemos, se debe a la conjunción de dos causas, una teológica y otra cultural. La teológica sería la demonología de la época que, al atribuir al demonio muchas concepciones y acciones humanas, descalifica a sus sujetos, incluso los condena a muerte, entregándose así inconscientemente al mismo mecanismo diábolico que pretende exorcizar. En este sentido dice Arriaga que, entre los sermones de la visita, uno debe explicar "cómo engañó el demonio a nuestros primeros padres y del pecado original y cómo de él proceden todos los pecados y errores que hay en el mundo" (244). Así pues, el error idolátrico de los indígenas provendría del pecado original, el cual, a su vez, provendría del engaño del diablo, y sería, más precisamente, una como repetición de ese engaño original, y ello porque un error tan mayúsculo sólo podía provenir del diablo. Los indígenas indoamericanos, sin embargo, estuvieron exentos de la Inquisición porque se les consideró no sólo neófitos, sino rudos, es decir, menores de edad; por eso en los autos de fe no se quemaron indígenas, porque no se les juzgaba sujetos sui iuris, plenamente responsables. Así les dice el visitador: "como ellos suelen castigar a sus hijos cuando son traviesos y no son obedientes, que así nuestra madre la Iglesia tiene mandado que les castiguen, pero con piedad y que les azoten con aquellas varas para absolverlos de la excomunión" (253).

Esta sería la segunda causa de que Arriaga considere que la religión indígena es del demonio: ha engañado a los indígenas por su poco juicio y así les puso unos ídolos y unas ofrendas que son cosa de burla. Nos parece que esta falta de aprecio, de estima, de valoración de los indígenas forma parte de la ideología del autor: ve a los indígenas a través de ella, y ella es la que da la perspectiva no sólo para entender y juzgar lo que ve, sino para proponer los caminos para su transformación. Decíamos que los indígenas reinterpretan el cristianismo desde su mundo religioso, considerándolo como la religión particular de la tribu española y a las imágenes cristianas como las huacas de los viracochas. Desde este punto de vista, piensan que, así como los incas les impusieron su religión mientras incluian a sus huacas en su panteón, así también ellos podían practicar la religión general de los nuevos dominadores, la nueva religión imperial y a la vez la suya particular ancestral. Pues bien, esa reelaboración indígena no podía, para el autor, provenir de ellos: sería un errror y engaño del demonio. De igual manera, esa forma sutil de mantener la cohesión cultural - la esperanza de que vendrá otro tiempo en que disminuirá la presión de los dominadores y ellos podrán continuar en paz con sus expresiones religiosas (tal vez una reinterpretación más atenuada y realista del Taki Onqoy) - no podía provenir de ellos, y tendría que ser cosa del diablo: "por impulso del demonio estaban persuadidos 
que tras de este tiempo vendría otro, donde podrían a su salvo volver a sus antiguallas con el descuido de sus pastores" (229). Como se puede apreciar, estas tres interpretaciones indígenas tienen en común que propician un espacio de libertad respecto de la ideología española y de pervivencia de la propia cultura. Pero esta independencia mental sería también demoníaca porque se asimilaría a una forma de rebeldía, que sería lo que transformó a Luzbel en Satán. Esto es lo que estaría en el fondo de la apreciación de Arriaga, aunque soterrada. Y así, aunque la visita tomaba la forma paternalista de una corrección a hijos menores descarriados por su poco seso, era en realidad un proceso inquisitorial contra rebeldes.

\section{Discusión sobre las causas y remedios}

Las causas de la persistencia de la idolatría y los medios que propone para desarraigarla lógicamente se corresponden, y como ya antes dijimos, pueden reducirse a dos capítulos: la implantación de una alternativa cristiana a la religión ancestral indígena y la erradicación sistemática de la idolatría y del campo cultural que le sirve de seno materno. En la visita y fuera de ella, para Arriaga ambos capítulos son concausas parciales que concurren en un mismo efecto y por tanto deben aplicarse unificadamente. El ejecutor principal de esos remedios, pero también el causante principal del actual estado de cosas es el cura doctrinero.

\subsection{El cura como factotum}

\section{a) Departamento para los indígenas}

Aquí está la primera anomalía, inherente, por cierto, al proyecto pastoral postridentino: la consideración del sacerdote como causa universal de todo lo eclesial. "En ellos están cifrados todos los demás medios y remedios de la cristiandad de los indios" (259), porque él es el ejecutor de todos. El problema aquí no está sólo en encontrar tales Atlantes que lleven sobre sus hombros a todos los indígenas y a esta Iglesia naciente, "porque acá pocos hay que quieren entrar a los gentiles si no es por puerta de oro o plata" (265), como le dice un corresponsal del norte del Perú, y lo corrobora otro de Bolivia: "parece que tienen odio, enemistad y mal sabor a las cosas de Dios, y casi tienen razón, porque los que les enseñamos mostramos el último fin de enriquecer en breve tiempo. $Y$ ha de ser con detrimento de las ovejas, que son trasquiladas sin piedad y amor" (227). $\mathrm{Y}$ aun en los casos de curas doctrineros celosos del bien de sus indios, el esquema de actuación está basado en la dicotomía estructural entre Iglesia docente e Iglesia discente, entre los que administran los dones de Dios y los que los reciben, lo que lleva al síndrome de la patemidad responsable: el misionero ejemplar que se mata por aquellos que Dios le encomendó, pero que todo lo hace él y 
no da participación a los otros, que es generosísimo, pero impide que los indígenas crezcan, ya que no les ofrece espacios y justifica esta radical falta de generosidad, afirmando que los indígenas aún no están preparados, cuando es él quien impide que crezcan y los mantiene como perpetuos menores de edad.

Existían indígenas con capacidades y deseos de ser misioneros de los suyos. Arriaga cuenta el caso de un cura doctrinero que renuncia a todo beneficio para evangelizar sin ningun título ni respaldo, "llevando sólo por compañero un buen indio cojo, que anduvo con nosotros en la visita y es tan entendido en las cosas de nuestra santa fe, como diligente escudriñador de las supersticiones de los indios, y por entrambas dos razones catequiza admirablemente" (228). ¿Por qué no se construyó una Iglesia fundada en indígenas de ese talante -como Guamán-, fieles a esa fe que abrazaron de todo corazón y fieles también a sus pueblos? ¿Por qué no se caminó en esa dirección? La respuesta es la incapacidad de concebir un cristianismo indígena. Así como, junto a la república de españoles, tuvo existencia real y legal una república de indios y ambas funcionaban dentro de la ecumene (aunque asimétrica y discriminadora) de las Indias, así pudo haber existido también, como otro componente de la república de indios, un cristianismo indígena, en comunión con los pastores comunes y con los hermanos cristianos de la república de los españoles, y un cristianismo que, al expresar el ser cultural indígena, hubiese enriquecido la catolicidad. Pero esto precisamente es lo que se trató de evitar, y se construyó, así, un departamento, digamos, para indígenas - aunque diseñado y llevado por no indígenas-, como un servicio especializado de una institución eclesiástica netamente española, aunque al servicio de todos. Si el sacerdote lo es todo y el sacerdote no puede ser indígena, sino mestizo, a lo más, y ello si es que hay virtud probada y letras (y si es letrado ya está blanqueado, pues las letras vienen obviamente de Europa), eso significa que los indígenas van a ser cristianos, pero no van a pertenecer a la Iglesia, ya que ésta quedó identificada con la institución eclesiástica. La Iglesia podía ser, en el mejor de los casos, para ellos; podía echar la suerte con ellos y hasta dar la vida por ellos, pero siempre como algo exterior a ellos. Ellos siempre serían destinatarios, receptores, nunca sujetos creadores.

\section{b) El cristianismo indígena}

Y sin embargo, la suya era la religión agraria, porque había nacido de ellos y porque eran ellos mismos los que la llevaban entre manos. Naturalmente, ellos no entendían que estaban dominando su religión y manejándola a su antojo. La religión era sagrada, tenía sus normas, pretendía ser la forma de obedecer al mundo divino, pero, en definitiva, era una obediencia recibida, interpretada y llevada a cabo por ellos mismos. Ya hemos dicho antes que la destinación al sacerdocio indígena era bastante fluida y además también existía el culto familiar y el de las chacras y acequias, que involucraba a mucha otra gente. Por eso, desde este punto de vista, podemos retomar y radicalizar la observación de 
Arriaga: "siendo comúnmente los indios inclinados a la veneración y adoración de Dios, bien se deja entender cuán poca ayuda tienen" (221), no sólo, como él piensa, por parte de los curas negligentes, sino también por los que son tan afanosos y diligentes que no dejan espacio para ellos, que les llaman, sí, a colaborar en sus planes, pero no se les ocurre planificar junto con ellos ni menos aún pedir a los indígenas que planifiquen ellos, quedando el sacerdote a la orden para colaborar con ellos.

¿Cuál fue el resultado de este exclusivismo clerical? Como los indígenas, ciertamente, eran muy religiosos, no se conformaron con su estatuto de puros receptores y reinterpretaron el catolicismo, viviéndolo desde sí mismos como sujetos, aunque sin entrar nunca en colisión con la institución eclesiástica, sino, por el contrario, integrándola a su mundo religioso, y de manera tan solapada que la institución eclesiástica pensó que eran los indígenas quienes se habían integrado por fin a su propuesta. No era ya ahora el ídolo tras el altar, sino la religión del pueblo (perfectamente católica) dentro de la religión de la institución eclesiástica, pero sin confundirse con ella: juntas pero no revueltas. Eso es lo que, hasta el día de hoy, la institución tiende a llamar catolicismo, religiosidad o piedad popular, pero que, como lo ha reconocido por fin, sin empacho, la Evangelii Nuntiandi, es la religión del pueblo.

\subsection{Doctrina sin evangelio}

\section{a) ¿Fue percibido el problema?}

Por otro camino se llegó también a constituir la religión (católica) del pueblo indígena: por lo insuficiente de la propuesta de la misión. Arriaga pinta patéticamente el abandono de la doctrina y del culto, y es obvio que de momento no había alternativa para la religión indígena, tan adaptada a su índole y cultura, según nuestro autor. Pero la que él propone, caso de ser llevada acuciosamente a la práctica, ¿constituye una alternativa válida? El catecismo del Tercer Concilio Limense, más los sermones que esboza el autor ( $c f .244-45$ ), ¿hubieran servido acaso para desengañar, como él dice, a los indígenas, desencantando a sus ojos la naturaleza? Aun en el caso de ser entendidos, los catecismos comunican a lo sumo una serie de verdades: "no sé yo qué cosa hay mayor ni más profunda que los misterios de nuestra santa fe, ni más dificultoso que dalles a entender de suerte que hagan concepto de ello los que tienen hecho el entendimiento a cosas tan materiales y rateras" (258). Pero ¿se propone alguna buena nueva? Además de librar a los indígenas de la presunta esclavitud del demonio, ¿qué bienes les otorgan? No creemos que Arriaga haya percibido este problema; más bien le parece que los misterios cristianos son buena nueva por hipótesis. Si esto es así, no tiene sentido preguntarse qué del cristianismo puede ser percibido por esas personas y esa cultura como una noticia buena para ellos y capaz de darles tal alegría que para entrar en ella estén dispuestos a desprenderse de lo que sea 
necesario.

\section{b) ¿Qué mueve al extirpador de la idolatría?}

Si el cristianismo no fue pensado expresamente como evangelio, podemos preguntarnos cuál era el móvil que llevaba al autor y a sus compañeros a embarcarse en un trabajo tan arduo, bajo el supuesto de que aquello que les urgía era también lo más valioso para ellos, dejando para más adelante la pregunta de si así lo captaban los índígenas. Sin duda el móvil de Arriaga es el que da el título al libro: La extirpación de la idolatría, desencastillando, como él dice, al diablo de la posesión que ha tenido tịanizada tantos años. Se trata, pues, de "remediar un mal tan encubierto". Claro está que para él derrocar al diablo es entronizar a Dios, y remediar el mal es alcanzar el bien, "que es la gloria de Dios que se sigue de que le conozcan y sirvan y amen los que no le amaban, ni servían, ni conocían" (272). Por eso acaba la relación de la visita refiriendo el contento en que quedan misioneros y visitadores, "viendo cuán diferente queda aquel pueblo de lo que le hallaron, encaminado a la vida eterna, ut cognoscant te, Deum verum et quem misisti Iesum Christum" (256).

Podemos suponer que enfrentarse en duelo a muerte con el mismísimo demonio para arrebatarle su presa y - como resultas de la victoria - implantar la bandera del recto conocimiento de Dios debió ser para estos sinceros creyentes una aventura totalizante. Por eso, concluye el autor diciendo que él piensa que cualquiera que tenga celo de la gloria de Dios y estima de las almas que tanto le costaron "quisiera tener mil vidas para empleallas todas en esta empresa" (273).

\section{c) El hombre para el sábado}

En este enfoque notamos un sutil deslizamiento: para el autor lo absoluto consiste en desarraigar la idolatría e implantar el recto conocimiento de Dios, y lo relativo, es decir, lo que de ahí se sigue como su consecuencia, es el bien de los indígenas. Esto último no es, pues, lo que se busca absolutamente, sino el efecto automático del móvil al que el autor consagra todas sus fuerzas. Ahora bien, si lo absoluto es la extirpación de la idolatría, entonces los indígenas no son sujetos absolutos, no son queridos por sí mismos, no son respetados como personas, como dignos en sí mismos. Los indígenas son destinatarios de la acción misionera, ayudantes u oponentes a ella; están referidos a esa acción, y son, pues, relativos, están en función de ella.

Esta absolutización de la extirpación de la idolatría relativiza a las personas. Los indígenas son sagrados en cuanto cristianos, no en cuanto idólatras, pero resulta que lo que de algún modo los totaliza es el ser idólatras; y por eso, la acción misionera busca salvar a los indígenas de sí mismos, de su radical alienación. Un indicio de que los indígenas eran considerados como sujetos absolutos hubiese sido hablar bien de ellos, al menos en algunos aspectos importantes, descubrir cualidades relevantes en ellos al margen de la cuestión de la idolatría, 
y, sobre todo, como decía Las Casas, preferir indígenas paganos vivos a indígenas cristianos muertos; indígenas dignos, aunque paganos, a indígenas cristianados, pero que han abdicado de su condición de sujetos.

Nada de esto se aprecia en esta obra. El autor no denigra a los indígenas ni los alaba, simplemente los considera en función sólo de la idolatría, que es la perspectiva englobante. Una muestra de cómo concibe la doctrina como algo absoluto y la cultura vivida de los indígenas como lo relativo es la frialdad con que encara el asunto de la localización de los pueblos y su falta de sensibilidad hacia las querencias de los ayllus. "Para este mismo fin ayuda también Su Excelencia por su parte, mandando que todos los pueblos que están desmembrados de su reducción sin orden del gobierno, los pueda quemar y disipar el visitador, para que vuelvan a su reducción; y así se ha hecho en muchos pueblos, y que los que con orden del gobierno están divididos, si le parece al visitador que no conviene, informe a Su Excelencia para que se manden reducir" (235).

Creemos que aquí confluyen nuevamente motivos teológicos y culturales. Desde la teología postridentina tiende a valorarse lo humano a partir de lo religioso y lo religioso a partir de la recta adoración. Además, si los indígenas son de corto entendimiento - como menores de edad- en su caso es más obvio que lo que les otorgará algún valor es entregarse a la religión verdadera. El significado de este desplazamiento consiste en poner al ser humano en función del sábado, sin considerar que lo religioso es un medio para el ser humano, y que lo humano es lo único absolutamente querido por Dios.

\section{d) De la alternativa misionera al cristianismo indígena}

Si éste es el móvil y perspectiva de misioneros y visitadores, ¿podían los indígenas captar la acción misionera como una buena nueva para ellos? Sí podrían captar como positivo el trabajo y desinterés de los misioneros, y también estamos dispuestos a creer a Arriaga cuando se refiere al "consuelo y contento" con que quedan los indígenas después de la visita por "conocer sus engaños y quedar enseñados y confesados". Es también cierto que da gozo liberarse de lo que la veneración a la tierra y a sus antepasados tiene de esclavitud y temor, y también se experimenta salvación al conocer un poco menos inexactamente a Dios y desechar "imágenes y representaciones" suyas demasiado inadecuadas. Por otra parte, salir del sistema adivinatorio para entrar en el de la confianza en Dios y el obrar razonable asumiendo el riesgo da miedo, pero también madura humanamente y causa alegría. Las constantes predicaciones de buenos oradores que buscaban sinceramente su bien, el que les dirigieran la palabra tan despaciosamente les hacía sentirse dignos, estimados, importantes. $Y$ las reuniones comunitarias, los cantos, las procesiones, incluso el elemento penitencial de las disciplinas, comprensible para ellos, es una re-creación de lo comunitario y del mundo ceremonial, que no podía menos de alimentar su espíritu. 
Sin embargo, en este nuevo sistema los elementos del ser cultural y religioso indígena quedan radicalmente desatendidos. Ante todo, la propia veneración a la tierra y los antepasados, y esa relación tan concreta, tan pormenorizada, digamos tan personal, con los seres divinos. El concepto tan dogmático de Dios, ¿no tendía a alejarlo, dejando el campo abierto para esas huacas de los cristianos que son las imágenes? En este sentido, el asimilar la figura de Jesús al mundo de los santos, si a nivel dogmático parece rebajarlo, a nivel del contacto religioso, ¿no es el modo de conservarlo cercano y de no relegarlo a las altísimas nubes del dogma? Luego está el sentido comunitario, sagrado y totalizador de la fiesta que, en la propuesta de la institución eclesiástica, se desliza hacia la ceremonia y el rito, dejando a un lado lo propiamente celebrativo, tenido como paganizante. Pero, sobre todo, está el hecho de que en esta nueva organización religiosa a ellos sólo les reservan el papel de receptores de servicios religiosos y ayudantes en la ejecución más material. Convocarles para oír la mismísima cartilla todos los meses y años, y a memorizarla, ¿no tenía que causar una insufrible aridez? Las misas y otras ceremonias en latín, en las que ellos no tenían ninguna participación, ¿cómo iban a alimentar a unas personas tan acostumbradas a la actuación personal y transida de sensorialidad en lo religioso? ¿Con qué espíritu religioso crecerían unos niños socializados religiosamente a punta de cartilla y memorización? ¿Qué experiencias religiosas se propiciaban en ellos?

Por eso "siendo comúnmente los indios inclinados a la veneración y adoración de Dios" tuvieron que construir por su cuenta su propia religión. Afincándose en lo devocional, que era lo único relativamente no codificado y accesible a ellos mismos, lo moldearán y actuarán como sujetos religiosos. En este ámbito relativamente abierto y libre fueron volcando su organización religiosa, y a partir de las experiencias se dió - por esa vía - una verdadera iniciación en el misterio cristiano, que la organización fue capaz de conservar y transmitir, y se fue elaborando como concepción religiosa, como pautas de comportamiento y como símbolos rituales, es decir, como una religión completa, que, sin embargo, a los ojos de la institución eclesiástica no aparecía como tal, sino solamente como el mundo realmente secundario, aunque frondoso, de lo devocional.

\subsection{La lógica del poder}

Para descubrir la idolatría y extirparla, y para acabar con los veneros en los que se incuba, Arriaga cree que hay que explicar, persuadir, amonestar; pero piensa también que es del todo imprescindible utilizar el poder de coacción y utilizarlo de un modo sistemático y generalizado, aunque tratando de moderar al máximo el rigor de las penas, como gente menuda que son. Así lo afirma a lo largo de todo el libro y lo estampa en frase lapidaria como resumen del capítulo sobre los medios para desarraigar la idolatría: "el día que hubiere castigo habrá enmienda" (240). Por eso, todo lo que propone Arriaga está fundado en último término en la obligatoriedad; no en el imperativo moral, sino en la coacción, es 
decir, en la amenaza de castigos si no se cumple lo mandado. La propuesta está basada, pues, en que los agentes religiosos son también representantes de los vencedores y actúan como tales. Su lógica es la lógica del poder: por las buenas o por las malas. Desean sinceramente que los indígenas acepten sus propuestas por las buenas; pero si no, se impondrán de todos modos en contra de su voluntad.

\section{a) El espíritu de la época}

Para Arriaga, la legitimidad del recurso a la fuerza se basa en que los indígenas son cristianos. Dejar el cristianismo no sólo es falta de lealtad con Dios, que los torna enemigos suyos, sino infidelidad a una institución, que ésta ni debe ni está dispuesta a tolerar, como un señor secular tampoco tolera la defección de un vasallo que un día libremente le juró fidelidad. Pero esa defección religiosa es a la vez un atentado político, ya que la unidad de la confesión religiosa es uno de los principales vínculos que dan solidez a una nación y a un Estado. Por eso, el Estado presta su consurso a la Iglesia para que la defección sea castigada y el relapso sea reducido a cumplir la palabra que empeñó.

Hay que reconocer que ése era el espíritu de la época, y por ello hay que dar, más bien, gracias a Dios de que a los indígenas los excluyeran de la jurisdicción de la Inquisición $-y$ de las penas de muerte que ésta imponía-, y es bien cierto que las penas que se les aplicaban eran cosa de risa en comparación con las que se aplicaban entonces en Europa. Sin embargo, esta observación no sirve de excusa, ya que, como muy certeramente observa el Documento de Consulta para Santo Domingo, el rechazo de la Ilustración a la religión positiva esta ligado "al repudio que suscitó la terrible y escandalosa experiencia de casi siglo y medio de guerras de religión. El cristianismo aparecía como factor de división de la sociedad, intolerante y excluyente" (n. 23). En el escrito que comentamos notamos en toda su virulencia ese talante intolerante y excluyente, que no suscita guerras de religión porque los contrincantes ya están vencidos y desarmados, pero no porque no funcione la misma lógica, sino porque no es necesario usar ya la violencia de la guerra ni la de las armas, sino que basta la de la represión: los azotes, la infamante trasquilada, las multas, la privación del cargo, el destierro y como pena máxima la reclusión en la Santa Cruz, construida en el cercado de Lima para sacerdotes indígenas recalcitrantes.

\section{b) ¿Existía el presupuesto para legitimar la coacción?}

Ahora bien, al hablar de las causas de la persistencia de las idolatrías, Arriaga pinta un cuadro del estado en que se encuentra el arzobispado que no permite avalar del todo ni el que los indígenas hayan sido bautizados libremente y con conocimiento de causa ni el que tengan una clara identidad cristiana. Como dice él mismo, "esta cordillera y sus vertientes hacia la mar del Sur están pobladas de indios cristianos, o por hablar más propiamente bautizados, y de la 
misma manera están otras provincias" (263). Así le escribe patéticamente un padre doctrinero: "Hanme quebrado el corazón y helo llorado con ellos muchas veces, diciéndoles cuán faltos estaban, cuán sin doctrina, sin Dios y sin ley" (253).

$Y$, sin embargo, el presupuesto de esta política es que los indígenas quieren ser cristianos, y que si conservan lo viejo es por ignorancia, por falta de altemativas y por miedo a sus sacerdotes. Este presupuesto no parece demasiado consistente, ya que aquí y allá se insiste en el arraigo de lo nativo, verdaderamente querido, y en cómo lo religioso indígena era canal eficaz para la constitución y conservación dinámica de la comunidad. Sin embargo, el presupuesto de la identidad cristiana, al menos como deseo, era indispensable para legitimar cristianamente la campaña y para llevarla a cabo no sólo con buena conciencia, sino con la conciencia de estar prestando un servicio señalado a los indígenas.

\section{c) La ambigüedad, factor de éxito}

El éxito de la campaña se debe a su ambigüedad. En definitiva, está basada en la coacción, pero quienes la proponen, la presentan como buena nueva para los indígenas, y ello porque así lo creen y porque subjetivamente sí quieren el bien de aquéllos. Además, a pesar de las amenazas, lo que se les propone en la primera visita es el perdón, previa confesión, eso sí, de la culpa perpetrada y el castigo merecido. Para eso se combinan dos mecanismos: el examen judicial del visitador, que en el fondo es una pesquisa inquisitorial, y la predicación que desengaña de los errores, propone el cristianismo como alternativa superadora y ofrece la confesión como arreglo total de cuentas. La ambigüedad está en que, aunque haya interés en distinguir ambas instancias, las dos son simultáneas "concurriendo como dos causas parciales a un mismo efecto". Por eso, los visitadores "de ninguna manera quieren ir sin los Padres" (242), ya que, de otro modo, quedaría patente su carácter inquisitorial y les quitaría la buena conciencia que tenían. Y en cuanto a ir padres solos, "han llegado Padres alguna vez a pueblos de indios sin visitador y no han sido bastantes para juntar la gente a sermón un día, cuánto más muchos, que son menester para enseñallos despacio y menos para hacelles confesar tan de propósito como la necesidad lo pide" (id.). "Pues sacalles los Padres a fuerza de predicación y doctrina las huacas, bien puede ser, pero pocas veces ha sido, y muchas se han hecho misiones" (id.).

Esta combinación de exhortación y amenaza, nacida del deseo de que los indígenas sean buenos cristianos, porque en eso se cifra su bien, y la confesión de que, en definitiva, el castigo es el gran motor de la doctrina, aparece en la siguiente carta de un doctrinero. Me falta, dice, "la paciencia cuando uso de amor y regalo. Cuando ya de aspereza y castigo, en diciéndoles que los tengo de enviar a la casa de Santa Cruz, lo temen, asústanse, vienen a misa y a la doctrina. Es esta casa su coco, castigo, cárcel y azote; tengo para mí fue la cosa mejor, 
más santa, buena y pía que se ha hecho" (235). Es cierto que es el recurso más habitual, tanto como amenaza cuanto como castigo ( $c f .198,203,233,238,239$, $240,259,260-261,268)$.

\section{d) El castigo como índice de la importancia de la religión: de la imposición de conductas a la iniciación indígena en el cristianismo}

La justificación ideológica de la necesidad del castigo también se basa en este caso en la misma razón cultural que apuntábamos más arriba: los indígenas son tan rudos, que el castigo es el único modo de que entiendan. Por eso, la benignidad y la permisividad serían en este caso criminales, ya que impidirian que los indígenas tomasen conciencia de su estado, porque ese tipo de gente, más que con argumentos, comprende y entra en razón con los castigos, y así si no se les aplican castigos por las idolatrías no llegan a percibir el grave pecado que éstas entrañan.

El argumento es válido si se quieren provocar conductas, es decir, si se pretende introyectar pautas desde el poder, regimentando a la colectividad indígena de un modo conductista para que resulte un orden uniforme y previsible, que sea funcional a la república de los españoles vencedores. Si esto es lo que de verdad se busca, es cierto que si los indígenas son castigados durísimamente por faltas mínimas en el servicio a los españoles y no se les castiga por la no adopción de las pautas religiosas, ellos inficren intuitiva y certeramente que a los vencedores no les interesa lo más mínimo qué religión practiquen los indígenas y que todo su interés se cifra en que los sirvan incondicionalmente. Y así ocurría en efecto. Pero este estado de cosas no podía ser convalidado ni por la corona (ya que la evangelización indígena era el título más indiscutible de la legitimidad de sus posesiones americanas) ni por los misioneros que eran los encargados de ejecutar esta política y que, en el caso de Arriaga y tantos otros, creían sinceramente en ella.

En estas condiciones, la falta de castigo de la idolatría evidenciaba la existencia de un crudo aprovechamiento del vencido, utilizado como botín de guerra, que invalida a los ojos del derecho de gentes (nacido precisamente en España con ocasión del hecho americano) la constitución de las Indias como una cristiandad. La conclusión del autor, a la luz del derecho de gentes, debía ser lógicamente acabar con esa opresión para que los indígenas captaran en los hechos la verdad de lo que proclamaban los funcionarios reales y los misioneros, es decir, el carácter misional y civilizatorio de la presencia española en América. Pero no es así, y como el autor se resigna a aceptar ese estado de cosas, sabe que no puede cambiarlo y que tiene que transar con él -y en definitiva, como hemos visto, apoyarse en él por el carácter coercitivo de su proyecto- no tiene más remedio que pedir que los castigos de los pecados indígenas contra el cristianismo sean de tal calibre que los indígenas capten que es un asunto que importa realmente a los españoles. 
Pero en estas condiciones, ¿puede avanzarse más allá de una socialización impuesta? Si el modo de producción determina el producto, ¿es posible que la religión cristiana, así impuesta, pueda ser captada como buena nueva por los indígenas? ¿Es posible en esas condiciones suscitar una verdadera experiencia? ¿Se abre así el camino para que los indígenas puedan iniciarse en el misterio cristiano? Por lo menos tenemos que decir que con estos métodos, completamente contrarios a la índole del evangelio, se hace extremadamente difícil el acceso de los indígenas a él. Sin embargo, los indios captaron a la larga - ya que tan real como la imposición abusiva de los misioneros, era la sinceridad con que los mismos se entregaban con todo desprendimiento a la misión- que los misioneros estaban convencidos de que el evangelio era indudablemente buena noticia de salvación para ellos. Los indios captaron la condición de evangelio de la religión cristiana, pero para preservarla de ese ambiente de violencia, tuvieron que hacerse cargo del evangelio tomándolo humilde y sigilosamente en sus manos, llevándolo a su casa para que allí, más allá de imposiciones y castigos, tuviese lugar la iniciación.

\section{e) El recurso al poder como falta de fe en el evangelio}

De todos modos, la radical falta de confianza en la fuerza intrínseca del evangelio que manifiesta el recurso a la fuerza como elemento imprescindible en la evangelización, el acostumbrarse al poder como vehículo de cristianización, es una pesada herencia de la que aún no se acaba de desprender la institución eclesiástica en América Latina. Y podemos decir que las tensiones actuales tienen que ver con las presiones que ejercen quienes se mantienen en este horizonte sobre los que lo han abandonado, presiones para que retornen al viejo esquema de poder, so pena de ser descalificados.

\subsection{Desarticular la cultura y la comunidad}

\section{a) Intervenir el trabajo y la fiesta}

En definitiva lo que se trata de quebrar es la cultura ancestral, pues se la ve inextricablemente unida a su religión. En este punto, Arriaga se aparta del parecer de Acosta. Este había asentado que "en los puntos en que sus costumbres no se oponen a la religión o a la justicia, no creo que se les deba cambiar así como así, hay que conservar sus costumbres patrias y tradiciones que no vayan contra la justicia, y organizarles jurídicamente conforme a ellas, tal y como ordenan las disposiciones del Consejo de Indias" (De Procuranda Indorum Salute, III, Madrid 1954, 585). Y comentando un texto de Gregorio Magno a Agustín en el transcurso de la misión inglesa - a la que, por cierto, también se refiere Arriaga - respecto del punto delicado de las fiestas, asienta que "puede permitirse alguna vez a los bárbaros celebrar convites y festejos solemnes en que coman y beban en público, siempre que sea en la plaza del pueblo, como ya 
prescribían las leyes de los incas. Si se hace así, no hay miedo de que proliferen tanto las grandes borracheras, puesto que lo estarán viendo y podrán castigarlo todos los nuestros" (id. 591).

Arriaga cree que no se da el presupuesto de Acosta de modo que se puedan separar tan netamente costumbres y religión, y el ejemplo serían precisamente las fiestas: los españoles las presenciaban, pero no eran capaces de ver allí la idolatría, que, sin embargo, sí existía. Arriaga ve sagazmente que los momentos fundamentales serían el trabajo comunitario y las fiestas, puesto que, como ya dijimos, están íntimamente asociados y mutuamente referidos, además de que la minga ya es una fiesta ( $c f .222-23$ ). Y por ello esto es lo que queda solemnemente estatuido en las constituciones que deja el visitador tras la visita: "Tendrá muy particular cuidado de estorbar las mingas que los indios hacen en tiempo de las sementeras para hacerlas bebiendo y cantando de que se siguen muy grandes ofensas a Dios Nuestro Señor, etc. Procurará con todo cuidado que cuando se hagan las dichas mingas sea dando a los mingados de comer y no de beber con el exceso y demasía que hasta aquí se ha hecho. / Item de aquí adelante por ningún caso ni color alguno, ni con ocasión de casamiento, fiesta del pueblo, ni en otra manera alguna, los indios e indias de este pueblo tocarán tamborinos ni bailarán, ni cantarán al uso antiguo, ni los bailes y cánticos que hasta aquí han cantado en su lengua materna, porque la experiencia ha enseñado que en los dichos cantares invocaban los nombres de sus huacas, malquis y del rayo, a quien adoraban, y al indio que esta constitución quebrantare le serán dados cien azotes y quitado el cabello con voz de pregonero que manifiesta su delito" (275).

\section{b) Quebrar la comunidad}

La organización del trabajo y la fiesta son las expresiones privilegiadas de la comunidad. Así, pues, todo está dirigido en último término a intervenir en la comunidad, a quebrar la solidaridad comunitaria, que no es una simple solidaridad mecánica, sino una solidaridad forjada muy concienzudamente a través de múltiples ensayos y complejos mecanismos a lo largo de muchas generaciones. Este es el fondo de la cuestión, que Arriaga capta con lucidez cuando asienta que "es cosa muy usada hacer todo lo que hacen por vía de comunidad" (223). Y dando un paso más, así caracteriza a la antropología indígena: "como decía muy bien el señor virrey don Martín Enríquez: todos los indios no solamente son unos, sino uno" (201).

No pretendo confundir esta comunitariedad con la comunión de los santos ni con la que Jon Sobrino llama "primera eclesialidad", que consiste en llevarnos los cristianos mutuamente en nuestra fe, pero sí tiene que ver con el concepto cristiano de solidaridad, que tan ampliamente ha desarrollado Juan Pablo II. Por ello, aunque tampoco identifiquemos, sin más, la comunitariedad indígena con la visión del Papa, lo menos que puede decirse es que constituye una "prepara- 
ción evangélica" en la que no estuvo ausente el Espíritu de Dios. Pero esto no podía percibirlo el individualismo postridentino que se desenvuelve en lo individual y lo masivo, pero que desconoce la dimensión comunitaria, porque nació persiguiéndola y reduciendo, así, a la Iglesia, no sólo teórica sino prácticamente, a la imagen y estructura de sociedad perfecta.

\section{c) La maquinaria implacable de la visita}

En el fondo, el dispositivo de la visita tiene por finalidad forzar la conciencia de los indígenas para romper la solidaridad étnico-religiosa y descubrir y desmontar el sistema religioso y organizativo en el que se basaba la sociedad indígena, de manera que, quedando éste desarticulado y los indígenas en la anomia, abrazaran la organización y el sistema cristiano de creencias y ritos. El que la visita sea sine die hasta que se descubra todo, el que el visitador venga con todos los hierros, es decir, con todo el poder del virrey y del arzobispo, el que en la asistencia general a los actos y en los interrogatorios del visitador, en los exámenes de doctrina y en las confesiones se proceda uno a uno, por padrón ( $c f$. $243,246,252,253,254$ ), tenía que crear un ambiente de angustia e intimidación, y, en definitiva, de inexorabilidad. A ello se sumaba el estupor que tenían que causar los secuestros de la gente más importante; la congoja, el conflicto de conciencia y la desmoralización que causaban las instancias agobiantes a la denuncia y a la delación; el dolor y el escándalo de la gente al ver afrentados a sus sacerdotes. Sobre todo, tenía que ser insufrible la presión a que se veían sometidas las autoridades. Y finalmente, la tortura, ya que, como dice paladinamente Arriaga, "en esta inquisición de la idolatría no se pueden guardar los ápices del derecho" (247), lo que no le parece particularmente grave pues sólo se pretende descubrir la verdad. Todo esto, adobado con oraciones, procesiones, disciplinas e innumerables sermones, para acabar de descubrir todo lo que ocul$\tan$. Como se echa de ver, se trata de una maquinaria formidable y bien aceitada, que, como insiste el autor, acaba logrando siempre su objetivo: "que es cierto que todos los indios visitados quedan enseñados, desengañados y escarmentados" (201).

\section{d) ¿Un dispositivo diabólico?}

Ahora bien, el precio de este método que fuerza la conciencia y la libertad, ¿no es matar el clima espiritual imprescindible para que se dé verdadera evangelización y no simple escarmiento y fría enseñanza? Aunque a decir verdad, ¿no habían apagado ya los misioneros en sí mismos el Espíritu al entregarse a unos métodos tan contrarios a la dignidad de la persona humana? ¿No es literalmente diabólico un dispositivo ordenado meticulosamente para dividir la comunidad, quebrar la solidaridad, provocar la delación y causar el desquiciamiento de los lazos más sagrados? ¿Es esta la división que ha venido a provocar Jesús o se trata del pecado contra el Espíritu Santo al llamar bien al mal? La cuestión es compleja y es pertinente plantearla. 
Es cierto que Jesús considera que, ante su invitación a seguirle, cualquier lazo debe ser relativizado, y, así, no hay que descartar la posibilidad de que sacerdotes o curacas hayan rehusado abrir su mundo religioso y cultural, y de este modo lo hayan absolutizado, impidiendo que elementos de la comunidad se abrieran al evangelio. Así ha de haber sucedido algunas veces, pero muchas otras no puede decirse que los indígenas hayan recibido una invitación personal al seguimiento de Jesús. Y en todo caso es totalmente distinta la división que, muy a su pesar, provoca el indígena cristiano en una comunidad pagana - por la que eventualmente puede ser discriminado o perseguido- que la que causan agentes cristianos en la comunidad indígena por el poder y la fuerza. Esto nunca puede ser cristianamente justificable. Lo más que podría admitirse es impedir el uso de la compulsión por parte de los paganos. Todo lo que pase de ahí es, independientemente de las intenciones, literalmente diabólico.

\section{e) El asedio a las autoridades: los sacerdotes indígenas}

Para quebrar la comunidad ancestral las piezas fundamentales son las autoridades y el enemigo principal es el sacerdote indígena. Se lo considera casi irreductible, ya que apenas se tiene esperanza en su rehabilitación. Por eso se busca más bien su rendición incondicional con la descalificación y el desprestigio consiguientes "porque así los vengan a tener en poco el común del pueblo" (238; cf. 255-56, 276-77). Se habla frecuentemente de los "hechiceros" o ministros "penitenciados" y se reconoce que a causa del trato recibido en la visita quedan "afrentados". Ellos son no sólo los guardianes de las huacas y los sacerdotes de su culto, sino también la memoria viva de sus mitos y el principal soporte de las tradiciones religiosas indígenas. En el fondo, los misioneros los ven como su contraparte, que se elimina sin ningún empacho porque el error no tiene derechos. El signo de que su acción contra ellos lleva la marca del Dios verdadero es que no sólo no se los mata, sino que tampoco se les abandona, y que tanto si se quedan en el pueblo como si son recluidos en la Santa Cruz se mira escrupulosamente por su sustento, e incluso se insta a los indígenas a que les den limosna, con lo que de paso se los mantiene en situación de inferioridad y minusvalía a los ojos de la comunidad.

\section{f) El asedio a las autoridades: los curacas y sus hijos}

Con el curaca la actitud es distinta. Por un lado, ellos también son depositarios de la cultura y tradición -y por lo tanto de su religión- y bajo este aspecto son oponentes. Pero, por otro lado, son líderes acostumbrados a mandar por herencia y desean seguir en el mando no sólo por razones económicas, sino de prestigio: sería una afrenta convertirse en indios del común. Pues bien, ellos tienen un lugar reconocido en el nuevo orden, pero con la condición de que sean leales a las nuevas autoridades y a la nueva religión. Si se avienen a la propuesta, pueden conservar todo el mando y el honor; en caso contrario, acabarán siendo desterrados. Es normal que los curacas deseen seguir siéndolo, y, por 
este motivo, a pesar de problemas de conciencia e incluso para salvar la cohesión de la comunidad e impedir la ruina total, estarán inclinados a aceptar la propuesta, y bajo este aspecto son ayudantes. Así, pues, con el curaca la actitud de entrada es de benevolencia y halago, aunque también de requerimiento a colaborar. Pero el supuesto es que el curaca tiene un lugar como tal en el nuevo orden, mientras que el sacerdote indígena tiene que dejar de serlo.

Naturalmente, se desea un curaca colaboracionista, pero, por otra parte, es necesario que mantenga su liderazgo y prestigio, ya que en caso contrario no sólo no es útil, sino fuente de problemas. Los encomenderos y otros españoles preferirían que se acriollara y que hiciera la función de intermediario de ellos para con los indígenas. Según el espíritu de las Leyes de Indias y desde el punto de vista cristiano debería ser más bien mediador entre unos y otros, leal a ambos, conservándose indígena, aunque conociendo la cultura española. $\mathrm{Al}$ curaca se le pide, pues, una transformación de envergadura histórica que serviría de paradigma para su comunidad. "Porque ellos hacen de los indios cuanto quieren, y si quieren que sean idólatras, serán idólatras, y si cristianos, cristianos, porque no tienen más voluntad que la de sus caciques, y ellos son el modelo de cuanto hacen" (222). En efecto, el texto presenta el ejemplo de un curaca que, con su renuencia religiosa, hacía completamente inútil el esfuerzo pastoral ( $c f$. 228), y Arriaga piensa que eso es lo que sucede —cuando él escribe- en la mayoría de los casos. De ahí la importancia de trabajar a los curacas: "importa mucho en estas misiones ganar a los caciques, acariciándoles y honrándoles, no pidiéndoles nada ni tomando nada de ellos (aunque algunos presentillos de cosas de comer se corren mucho si no los toman) y dándoles de las cosas que llevamos de devoción. Porque ganada la puerta de los curacas, no hay dificultad en descubrir todas las huacas e idolatrías" (239). Y para los recalcitrantes existen castigos que llegan hasta a privarlos del cargo y enviarlos a la mita o a la Santa Cruz.

Sin embargo, el autor también constata que estas provisiones del virrey no suelen ejecutarse. La razón es que los curacas han contraído vínculos con la administración española y ésta no está dispuesta a correr costos por cosa de religión, porque, como decíamos más arriba, en el caso de los criollos y funcionarios medios no es la religión lo que mueve sus decisiones. La religión es sacrificada a la economía. Los curacas son conscientes de esta situación y se aprovechan de ella.

Por eso, a la larga, la solución es la educación de sus hijos en colegios especiales, "porque cuales fueren ellos después tales serán todos sus indios" (199). Por eso, la orientación de esos colegios indica la dirección que quiere promoverse: "que desde muchachos aprendan la policía y la religión cristiana" (239). Es decir, no se piensa ya en la mediación, sino en la asimilación: en que sean agentes de socialización de la cultura y religión española entre los suyos. 
En resumidas cuentas también por este camino se echa de ver la desconfianza y falta de aprecio respecto de la cultura indígena y el propósito de quebrarla para introducir el cristianismo y la cultura hispánicas mediante la quinta columna de los jóvenes curacas.

\subsection{Un abuso de poder}

En definitiva, ¿por qué tomar este atajo de la compulsión en vez de seguir el camino real de la conversión personal, a través de la presentación dilatada e inculturada del cristianismo y de la constitución de comunidades cristianas que hubieran servido de ejemplo como levadura de la comunidad y en comunión con ella y que hubieran proporcionado misioneros para evangelizar desde dentro a los pueblos indígenas? Ya lo dijo Acosta: porque son bárbaros. En definitiva, porque son los vencidos. Como afirmaba Sepúlveda paladinamente, este es un método más expedito, siempre, claro está, que se tenga el poder para aplicarlo. Es, pues, un abuso de poder, aunque se lleve a cabo con el mayor cuidado posible, con la mayor buena voluntad y aun con conciencia mesiánica.

Pero el poder, si de buenas a primeras parece irresistible y barre con todo, a la larga se mella, y si, como en este caso, los vencidos resisten, acaban siendo invulnerables. Si los indígenas de la sierra peruana son cristianos es porque, en último término, ellos lo decidieron así - y por eso lo son a su modo-, no por tanto irrespeto, violencia y destrucción. Si la violencia no es cristiana ni evangélica, la violencia religiosa es la que menos justificación puede encontrar, y si no se ven así las cosas es porque se practica una religión alienada en la que el ser humano es para el sábado. Es una mala fe, y mala fe es una fe en Dios que no se media por la fe en los seres humanos, en este caso los indígenas. Es una entrega esforzada a los indígenas sin fe en ellos. Es la violación sistemática de su condición de seres humanos, no percibida como tal porque se hace en nombre de la Verdad y para su bien, que se pretende conocer mejor que ellos. Mala fe es la intención de hacer el bien que se lleva a cabo cometiendo el mal; en este caso, violentando cuerpos y conciencias. Así, este libro de Arriaga aparece como paradigma de un modo de entender la misión y la pastoral que no puede decirse que es cosa sólo del pasado.

\section{NOTA BIBLIOGRAFICA}

Además del Libro de Arriaga, quienes participaron de esta campaña de estipación de idolatrías produjeron libros ad hoc. Francisco de Avila, además de sus Dioses y hombres de Huarochirt (Ed. Museo Nacional de Historia, Lima 1966) escribió en 1611 una memoria de su primera visita, que publicó José Toribio Medina en su estudio sobre La Imprenta en Lima (ver en Esteve Barba: Historiografia Indiana. Ed. Gredos, Madrid 1964, 490). Hernando Avendaño es autor de una breve relación publicada por Medina en la 
obra citada (ver Esteve Barba 491). Años antes, como resultado de una campaña anterior, Cristóbal de Albomoz había escrito una Instrucción para descubrir todas las guacas del Pirú y sus camayos y haciendas (Journal de la Societé des Americanistes 56, $\mathrm{n}^{2} 1,1967$, 17-39).

La descripción y valoración que hace Arriaga de la religión indígena se apoya en el Confesionario para los curas de indios con una instrucción contra sus ritos, que por mandato del Tercer Concilio Limense, editó en 1585 Antonio Ricardo, precisamente en el colegio de San Martín de Lima donde residía Arriaga. Esta Instrucción está influida por José de Acosta: Historia Natural y Moral de las Indias, I. V. (BAE, Madrid 1987, 247-77), donde no sólo describe la idolatría sino que trata también del modo de desarraigarla. Acosta se apoya en Polo de Ondegardo a quien trató, que es autor De los errores y supersticiones de los indios, incluido por influjo de Acosta en el Confesionario del III Concilio que citamos arriba. Escribió además en 1571 Informaciones acerca de la Religión y Gobierno de los incas (Lima 1915. Citado en nota De Procuranda ... 38). El Catecismo del III Concilio Provincial de Lima y sus complementos pastorales ha sido publicado por Juan Guillermo Durán en sus Publicaciones de la Facultad de Teología de la Universidad Católica de la Argentina, Buenos Aires 1982.

Una visión altemativa de la religión indígena puede encontrarse en los mestizos Blas Valera, al que se atribuye la Relación de las costumbres antiguas de los naturales del Pirú (En Crónicas Peruanas de Interés Indígena. BAE, Madrid 1968,151-89) y el Inca Garcilaso de la Vega, en sus Comentarios Reales (Biblioteca Ayacucho $n^{9} 5$ y 6, Caracas 1985) que cita abundantemente y con encendido elogio a Valera. Guamán Poma en su Nueva Crónica y Buen Gobierno (Biblioteca Ayacucho n 75 y 76, Caracas 1980) también crítica a los extripadores, aunque los acompaño en su campaña y coincide con ellos en la existencia de la idolatría, pero les reprocha ver idolatría en todo lo indígena y su ceguera en no percibir la idolatría mucho más grave de los españoles.

Entre los estudios actuales sobre el tema citaremos a Duviols: La destrucción de las religiones andinas. Universidad Autónoma de México, México 1977. Marzal: La transformación religiosa peruana. Pontificia Universidad Católica del Perú. Lima 1983, 119. 440. Vargas Ugarte: Historia de la Iglesia en el Perú, tomo II (1570-1640) Burgos 1959, 305-329. Borges: Métodos misionales en la cristianización de América. C.S.I.C., Madrid 1960, 247-306. Millones: Historia y poder en los Andes centrales. Alianza, Madrid 1987, 166-85. Stern: Los pueblos indigenas del Perú y el desafío de la conquista española. Alianza, Madrid 1986, 78-132,278-92. 